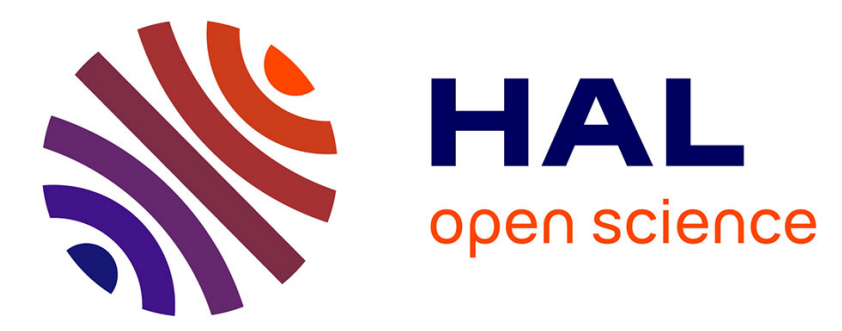

\title{
Zinc and cobalt complexes based on tripodal ligands: synthesis, structure and reactivity toward lactide.
} Mathieu J-L Tschan, Jia Guo, Sumesh K Raman, Emilie Brulé, Thierry Roisnel, Marie-Noelle Rager, Rémi Legay, Guillaume Durieux, Baptiste Rigaud, Christophe M Thomas

\section{To cite this version:}

Mathieu J-L Tschan, Jia Guo, Sumesh K Raman, Emilie Brulé, Thierry Roisnel, et al.. Zinc and cobalt complexes based on tripodal ligands: synthesis, structure and reactivity toward lactide.. Dalton Transactions, 2014, 43 (11), pp.4550-64. 10.1039/c3dt52629a . hal-01016948

\section{HAL Id: hal-01016948 \\ https://hal-univ-rennes1.archives-ouvertes.fr/hal-01016948}

Submitted on 1 Jul 2014

HAL is a multi-disciplinary open access archive for the deposit and dissemination of scientific research documents, whether they are published or not. The documents may come from teaching and research institutions in France or abroad, or from public or private research centers.
L'archive ouverte pluridisciplinaire HAL, est destinée au dépôt et à la diffusion de documents scientifiques de niveau recherche, publiés ou non, émanant des établissements d'enseignement et de recherche français ou étrangers, des laboratoires publics ou privés. 




This is the author's final draft post-refeering (post-print)

Find more peer-reviewed articles on our open access repository:

http://hal-univ-rennes1.archives-ouvertes.fr/ 


\title{
Zinc and cobalt complexes based on tripodal ligands: synthesis, structure and reactivity toward lactide $\dagger$
}

\author{
Mathieu J.-L. Tschan, ${ }^{a}$ Jia Guo, ${ }^{a}$ Sumesh K. Raman, ${ }^{a}$ Emilie Brulé, ${ }^{a, b}$ Thierry Roisnel, ${ }^{c}$ \\ Marie-Noelle Rager, ${ }^{d}$ Rémi Legay, ${ }^{e}$ Guillaume Durieux, ${ }^{a}$ Baptiste Rigaud ${ }^{e}$ and \\ Christophe M. Thomas*a
}

The coordination chemistry of a series of pro-ligands $\left(\left[\mathrm{L}^{\mathbf{1}}\right]-\left[\mathrm{L}^{6}\right]\right)$ with cobalt and zinc derivatives has been studied. All complexes have been characterized by multinuclear NMR, elemental analysis, and by singlecrystal X-ray diffraction studies. Polymerization of rac-lactide takes place at $130{ }^{\circ} \mathrm{C}$ in the presence of cobalt and zinc complexes to yield polymers under solvent free conditions with controlled molecular masses and narrow polydispersities.

\section{Introduction}

Biodegradable polymers have recently gained great attention as a replacement for synthetic (petroleum-based) materials. ${ }^{1}$ Among the new biodegradable polymers that have been developed during the last decade, ${ }^{2}$ polylactides (PLAs) are of particular interest. ${ }^{3}$ The availability of monomer feedstocks from renewable resources has given PLAs an increasing prominence in the market place. ${ }^{4}$ Methods for the synthesis of these polymers now rely on the controlled ring-opening polymerization (ROP) of lactide by well-defined metal initiators, which produce high-molecular-weight polymers with interesting mechanical properties. ${ }^{5}$ The coordination-insertion mechanism of lactide polymerization proceeds via coordination of the monomer to the metal centre, followed by insertion into the metal-alkoxide species through the acyl-oxygen bond with retention of configuration. This results in a new metal-alkoxide species capable of further insertion. In a biomimetic spirit, ${ }^{6}$ a mechanistic analogy may be drawn between this process and

\footnotetext{
${ }^{a}$ Institut de Recherche de Chimie Paris, CNRS - Chimie ParisTech, 11 rue Pierre et Marie Curie, 75005 Paris, France.E-mail: christophe.thomas@chimie-paristech.fr; Fax: +33(0)143260061; Tel: +33(0)144276721

${ }^{b}$ Université Pierre et Marie Curie, 4 Place Jussieu, 75005 Paris, France

${ }^{c}$ Centre de Diffractométrie X, UMR CNRS 6226, Université de Rennes 1, 35042 Rennes, France

${ }^{d}$ Chimie ParisTech, NMR Facility, 11 rue Pierre et Marie Curie, 75005 Paris, France ${ }^{e}$ Université de Caen, ENSICAEN, UMR 6507, 6 Boulevard Maréchal Juin, 14050 Caen, France

$\dagger$ Electronic supplementary information (ESI) available. CCDC 962580, 962577, 962579, 962578, 962576 and 962522. For ESI and crystallographic data in CIF or other electronic format see DOI: $10.1039 / \mathrm{c} 3 \mathrm{dt} 52629 \mathrm{a}$
}

the hydrolysis reactions performed by a large class of zinc metalloenzymes.

The ubiquity of zinc in metalloenzyme chemistry has been related to its flexible coordination chemistry, substitutional lability, Lewis acidity, combined with intermediate polarizability. $^{7}$ Much of the importance of zinc enzymes originates from their amidase activity involving the cleavage of amide bonds. ${ }^{8}$ For instance, the metallo $\beta$-lactamase scaffold is designed to accommodate one or two zinc ions able to activate a nucleophilic hydroxide for the hydrolysis of the $\beta$-lactam ring. Upon substitution with $\mathrm{Co}^{2+}$, the resulting enzyme is a more efficient catalyst than the native enzyme for the hydrolysis of some $\beta$-lactams suggesting that the role of the metal centre is principally to provide the nucleophilic hydroxide, rather than to act as a Lewis acid to polarize the carbonyl group. ${ }^{7 b}$

In our search for new polymerization catalysts, we focused our efforts on investigating the catalytic activity of mononuclear zinc and cobalt complexes supported by tripod ligands. ${ }^{9}$ The coordination chemistry of tripod ligands has been intensively studied in recent years. Of particular interest are pyrazolylborate ligands to which Vahrenkamp and Parkin have contributed synthetic, model complex, and complex reactivity studies. ${ }^{10}$ Another important class of tripod ligands are tris(picolyl)amine derivatives which can easily be obtained with different donor arms. Depending on the nature and number of donor groups, such compounds can accommodate a broad range of coordination geometries as multidentate ligands for various metal centres. Some of the resulting complexes can be used as efficient catalysts in a variety of processes. Early reports on tripodal ligands were focused on the coordination properties of monoanionic phenoxy based ligands of the type $\left[\mathrm{L}_{2} \mathrm{NO}\right]^{-}$but there is no example of a 
multidentate ligand with soft phosphorus donor atoms. ${ }^{11}$ Therefore we decided to investigate the coordination of tripodal containing $\left[\mathrm{L}_{2} \mathrm{NO}\right]$ and $\left[\mathrm{L}_{3} \mathrm{~N}\right]$ donor environments and the catalytic behavior of the corresponding zinc and cobalt chloride complexes.

Although efficient single site initiators have been reported for the controlled ROP of lactide, a great challenge remains in performing catalytic polymerization of lactide, thus optimizing productivity of the metal-based species and minimizing contamination of polymer with metal residues. Inoue first reported the use of metalloporphyrins in the immortal polymerization of lactones using transfer agents such as alcohols. ${ }^{12}$ This initial discovery inspired the development of other catalytic systems. ${ }^{13}$ As already mentioned, model studies of different zinc enzymes have been used to determine how the coordination environment around the zinc centre affects the activity of the model. To this end, researchers have constructed active zinc enzyme mimics. In particular, tripodal zinc complexes have been widely investigated as models. For instance, it has been shown that, in the presence of methanol or ethanol, a tris(pyrazolyl)borate zinc complex acts as a catalyst for the ring-opening of $\beta$-butyrolactone, resulting in the formation of the corresponding esters of $\beta$-hydroxybutyric acid. In this regard, we envisaged that our $\left[\mathrm{L}_{2} \mathrm{NO}\right] \mathrm{M}(\mathrm{Cl})_{n}$ and
$\left[\mathrm{L}_{3} \mathrm{~N}\right] \mathrm{M}(\mathrm{Cl})_{n}$ chloride complexes would have the potential to be labile to alcohol exchange; that is, a rapid exchange would occur between the metal species and alcohol. Since the growing species of lactide polymerization is an alkoxide, alcohol would then behave as a reversible chain transfer agent. Herein we report the synthesis, characterization, and LA polymerization reactivity of different zinc(II) and cobalt(II) complexes.

\section{Synthesis and structural characterization of the pro-ligands}

The tripodal pro-ligands described in this study were prepared in a straightforward manner, by reductive amination, following a one-pot procedure using commercially available or easily accessible starting materials (Fig. 1). ${ }^{11 c, 14,15}$ The new compounds $\left[\mathbf{L}^{2}\right] \mathbf{H},\left[\mathbf{L}^{3}\right] \mathbf{H}, \mathbf{L}^{\mathbf{4}}$, and $\mathbf{L}^{\mathbf{5}}$ were obtained in good to excellent yields. $\left[\mathbf{L}^{3}\right] \mathrm{H}$ was prepared by two successive reductive amination reactions from picolyl amine, introducing first the phenolic moiety followed by the phosphine arm. $\mathbf{L}^{\mathbf{5}}$ is obtained in a one-step reaction between diphenylphosphinobenzaldehyde and an ammonium salt. All compounds were obtained as colourless or yellowish powders, and their identity was confirmed by NMR and high-resolution mass spectrometry or elemental analysis. Such a ligand architecture allows for steric



Fig. 1 Synthesis of $\left[L^{n}\right]$. 


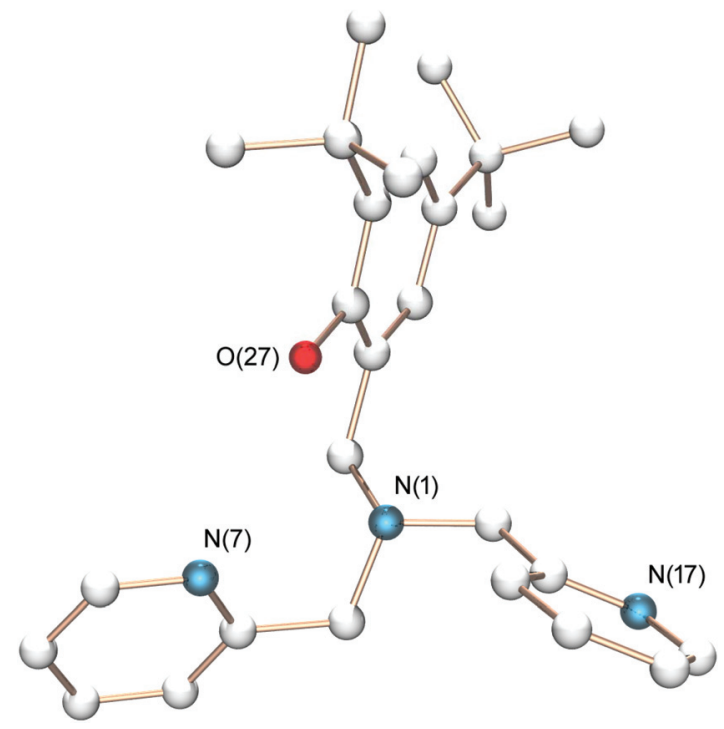

Fig. 2 Molecular structure of pro-ligand $\left[L^{1}\right] \mathrm{H}$ (hydrogen atoms and solvent molecules are omitted for clarity).

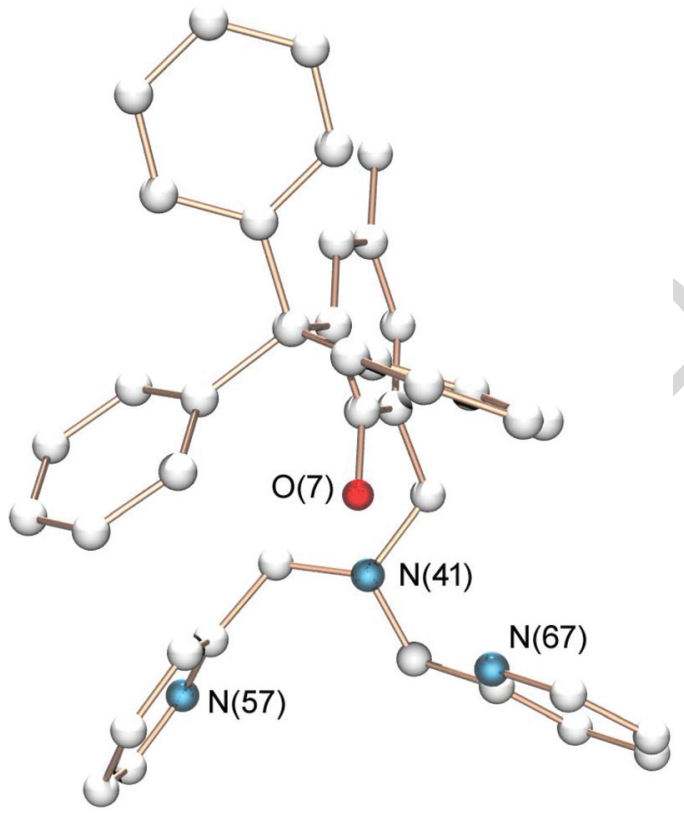

Fig. 3 Molecular structure of pro-ligand $\left[\mathrm{L}^{2}\right] \mathrm{H}$ (hydrogen atoms and solvent molecules are omitted for clarity).

and electronic variations on the different donor fragments (Fig. 1).

The crystal structures of compounds $\left[\mathbf{L}^{1}\right] \mathbf{H},\left[\mathbf{L}^{2}\right] \mathbf{H}, \mathbf{L}^{4}, \mathbf{L}^{5}$, and $\mathbf{L}^{5} \cdot \mathbf{H C l}$ were determined by $\mathrm{X}$-ray diffraction studies (Fig. 2-6). A summary of the relevant crystallographic data and refinement parameters for $\left[\mathbf{L}^{1}\right] \mathbf{H},\left[\mathbf{L}^{2}\right] \mathbf{H}, \mathbf{L}^{4}, \mathbf{L}^{5}$ and the protonated ligand $\mathbf{L}^{5} \cdot \mathbf{H C l}$ can be found in Table 1. Interestingly, the molecular structure of the ammonium cation $\left[\mathbf{L}^{5} \mathbf{H}\right]^{+}$(Fig. 6)

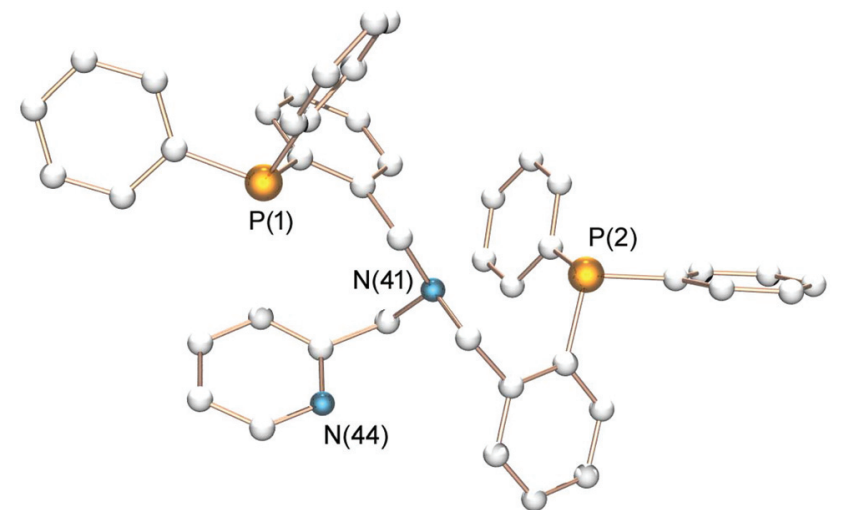

Fig. 4 Molecular structure of pro-ligand $\mathrm{L}^{4}$ (hydrogen atoms are omitted for clarity).

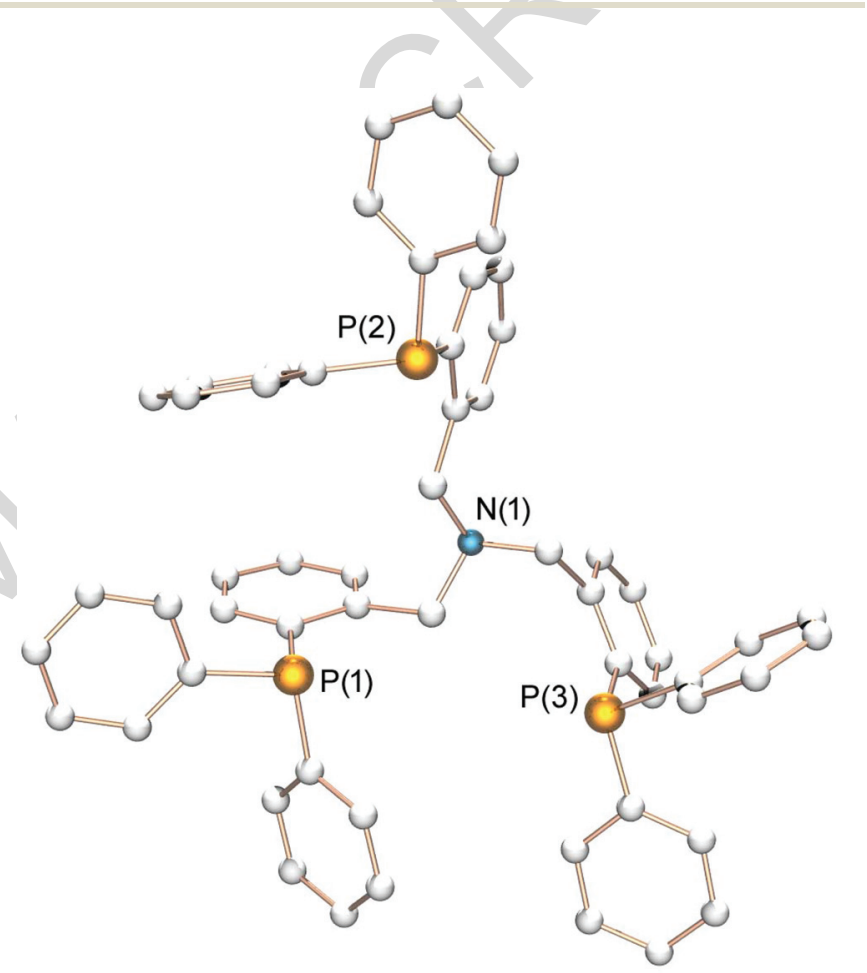

Fig. 5 Molecular structure of tripodal pro-ligand $\mathrm{L}^{5}$ (hydrogen atoms are omitted for clarity).

revealed the steric properties of pro-ligand $\mathbf{L}^{5}$ in a structural motif akin to that involving metal coordination, due to the interaction of all coordinating atoms, the nitrogen and the three phosphorus atoms with the proton H1. These interactions are evidenced when comparing with the molecular structure of $\mathbf{L}^{\mathbf{5}}$ (Fig. 5) in which the tripod minimizes the steric interactions between all atoms. Considering the plane containing the three methylenic carbons, the nitrogen atom is above the plane and the three phosphorus atoms located on the other side; the lone pair of nitrogen is pointing outwards from the $\mathrm{NP}_{3}$ tetrahedra. In $\left[\mathbf{L}^{5} \mathbf{H}\right]^{+}$, the proton is inside the $\mathrm{NP}_{3}$ tetrahedra, showing the cavity that could create the ligand $\mathbf{L}^{\mathbf{5}}$ around a metal centre upon coordination. 


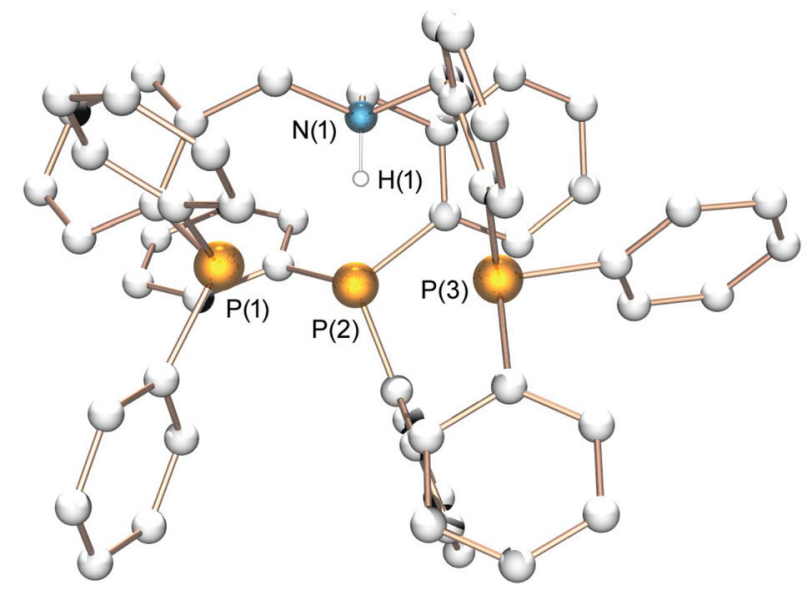

Fig. 6 Molecular structure of tripodal ammonium salt $\mathrm{L}^{5} \cdot \mathrm{HCl}$ (hydrogen atoms and chloride anion are omitted for clarity).

\section{Synthesis and structural characterisation of the cobalt(II) and} zinc(II) complexes

The coordination chemistry of the ligands was studied towards zinc and cobalt dichloride. $\left[\mathrm{L}_{2} \mathrm{NO}\right]$ and $\left[\mathrm{L}_{3} \mathrm{~N}\right]$ ligands were used to synthesize a series of twelve new complexes 1-12, such as $\left[\mathrm{L}_{2} \mathrm{NO}\right] \mathrm{MCl}$ and $\left[\mathrm{L}_{3} \mathrm{~N}\right] \mathrm{MCl}_{2}(\mathrm{M}=\mathrm{Zn}, \mathrm{Co})$. Reactions of the neutral pro-ligands $\mathbf{L}^{\mathbf{4}}, \mathbf{L}^{\mathbf{5}}$, and $\mathbf{L}^{\mathbf{6}}$ with one equiv. of $\mathrm{ZnCl}_{2}$ or $\mathrm{CoCl}_{2}$ in tetrahydrofuran at $50{ }^{\circ} \mathrm{C}$ afford cleanly the bischlorozinc and -cobalt complexes 4-6 and 10-12 (Fig. 7). These compounds were isolated in good yields and are readily soluble in chlorinated solvents. These complexes were characterized by elemental analysis, NMR spectroscopy and molar conductivity, UV/Vis measurements, and X-ray diffraction studies for some of them. The results of molar conductivity measurements suggest that all zinc complexes are non-electrolytes in DMF (see ESI $\dagger$ ). In accordance with previous studies and ${ }^{1} \mathrm{H}$ NMR data (vide infra), these observations are indicative of the formation of (di)chloride species, in which one of the pyridyl/ phosphino moieties may remain uncoordinated. By contrast the molar conductivity values of cobalt(II) dichlorides indicate that one of the coordinated chloride has been replaced by a DMF molecule. This assignment of cationic structures was supported by UV/Vis analyses of 7, 9 and 11.

The monochloro zinc and cobalt complexes 1-3 and 7-9 were synthesized via a salt metathesis route (Scheme 1). The salt metathesis reactions are two-step reactions. First a solution of the pro-ligand is combined with sodium hydride in order to form an anionic phenoxide. In a second step, the preformed sodium-phenoxide is added to a metal chloride and the synthesis of the metal complex is accompanied by the formation of sodium chloride. As an example, the synthetic scheme for the preparation of $\mathbf{1}$ is shown in Scheme 1. The coordination of the ligand $\mathbf{L}^{\mathbf{1}}$ to the zinc metal centre is confirmed by ${ }^{1} \mathrm{H}$ NMR analysis (Fig. 8). Firstly, the signal of the pyridine $\alpha$-proton is shifted from $8.4 \mathrm{ppm}$ to $9.4 \mathrm{ppm}$. Secondly, an $\mathrm{AB}$ pattern for benzylic $\mathrm{CH}_{2}$ protons confirms the non-equivalence of the benzylic protons of each picolyl arm upon coordination ( $\mathrm{C}-\mathrm{C}$ bond rotation is now impossible). Finally, the benzylic protons of the phenolic arm remain equivalent and appear as a singlet in the ${ }^{1} \mathrm{H}$ NMR spectrum, suggesting the formation of a monomeric species with rigid $C_{\mathrm{s}}$

Table 1 Summary of X-ray data collection and refinement

\begin{tabular}{|c|c|c|c|c|c|c|}
\hline & {$\left[\mathbf{L}^{1}\right] \mathbf{H}$} & {$\left[\mathbf{L}^{2}\right] \mathbf{H}$} & $\mathbf{L}^{4}$ & $\mathbf{L}^{5}$ & $\mathbf{L}^{5} \cdot \mathrm{HCl}$ & 2 \\
\hline Empirical formula & $\mathrm{C}_{27} \mathrm{H}_{35} \mathrm{~N}_{3} \mathrm{O}$ & $\mathrm{C}_{39} \mathrm{H}_{35} \mathrm{~N}_{3} \mathrm{O}$ & $\mathrm{C}_{44} \mathrm{H}_{38} \mathrm{~N}_{2} \mathrm{P}_{2}$ & $\mathrm{C}_{57} \mathrm{H}_{48} \mathrm{NP}_{3}$ & $\mathrm{C}_{60} \mathrm{H}_{52} \mathrm{Cl}_{10} \mathrm{NP}_{3}$ & $\mathrm{C}_{45} \mathrm{H}_{40} \mathrm{ClN}_{3} \mathrm{OZn}$ \\
\hline Formula weight & 417.58 & 561.7 & 656.7 & 839.9 & 1234.44 & 739.62 \\
\hline Wavelength $(\AA)$ & 0.71073 & 0.71073 & 0.71073 & 0.71073 & 0.71073 & 0.71073 \\
\hline Crystal system & Monoclinic & Triclinic & Monoclinic & Triclinic & Triclinic & Monoclinic \\
\hline Space group & $P 21 / n$ & $P \overline{1}$ & $P 2_{1} / c$ & $P \overline{1}$ & $P \overline{1}$ & $P 2_{1} / n$ \\
\hline$a(\AA)$ & $10.052(2)$ & $10.9042(6)$ & $14.0718(9)$ & $15.6653(16)$ & $10.8501(19)$ & $9.1363(15)$ \\
\hline$\beta\left({ }^{\circ}\right)$ & $110.971(12)$ & $91.203(2)$ & $98.664(2)$ & $112.551(4)$ & $95.702(6)$ & $91.470(11)$ \\
\hline$c(\AA)$ & $10.268(2)$ & $14.7332(7)$ & $19.6384(9)$ & $18.1172(19)$ & $20.392(3)$ & $19.679(4)$ \\
\hline$\gamma\left(0^{\circ}\right)$ & 90 & $104.786(2)$ & 90 & $92.618(4)$ & 96.184(7) & 90 \\
\hline$V\left(\AA^{3}\right)$ & $2372.4(9)$ & $1860.58(16)$ & $3704.0(4)$ & $4637.0(8)$ & $3021.8(8)$ & $3958.6(14)$ \\
\hline$Z$ & 4 & 2 & 4 & 2 & 2 & 4 \\
\hline$D_{\mathrm{c}}\left(\mathrm{g} \mathrm{cm}^{-}\right.$ & 1.169 & 1.003 & 1.178 & 1.203 & 1.357 & 1.241 \\
\hline Unique reflections & 5268 & 8390 & 8432 & 20787 & 13664 & 8975 \\
\hline$R_{\text {int }}$ & 0.069 & 0.0481 & 0.0504 & 0.0637 & 0.0554 & 0.2219 \\
\hline Variable parameters & 282 & 391 & 433 & 1099 & 671 & 407 \\
\hline Goodness-of-fit & 1.013 & 1.093 & 1.055 & 1.038 & 1.052 & 0.912 \\
\hline$R_{1}, \mathrm{w} R_{2}(I>2 \sigma)^{a}$ & $0.0672,0.1496$ & $0.0524,0.1518$ & $0.0451,0.122$ & $0.0488,0.1132$ & $0.0631,0.1481$ & $0.0986,0.2197$ \\
\hline 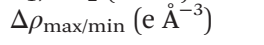 & $0.28,-0.262$ & $0.243,-0.235$ & $0.32,-0.259$ & $0.356,-0.34$ & $1.563,-1.534$ & $0.798,-1.086$ \\
\hline
\end{tabular}

${ }^{a} R_{1}=\sum|| F_{\mathrm{o}}|-| F_{\mathrm{c}}|| / \sum\left|F_{\mathrm{o}}\right| ; \mathrm{w} R_{2}=\left\{\sum\left[\mathrm{w}\left(F_{\mathrm{o}}{ }^{2}-F_{\mathrm{c}}{ }^{2}\right)^{2}\right] / \sum\left[\mathrm{w}\left(F_{\mathrm{o}}{ }^{2}\right]\right\}^{1 / 2}\right.$. 




1

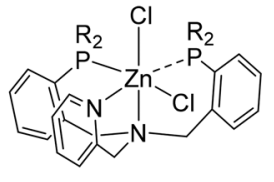

4
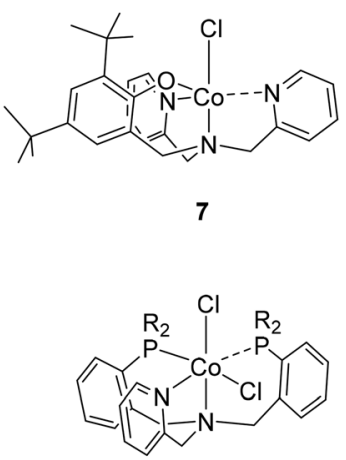

10

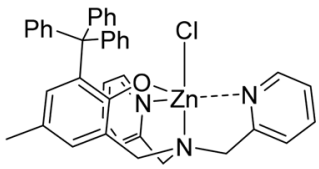

2
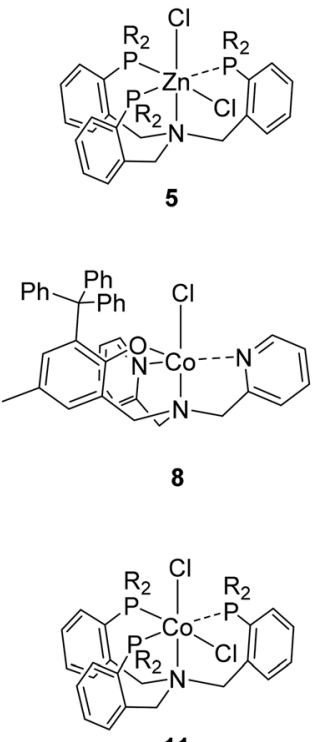

11

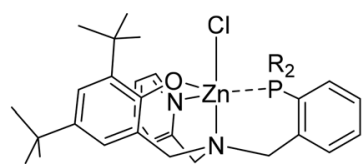

3
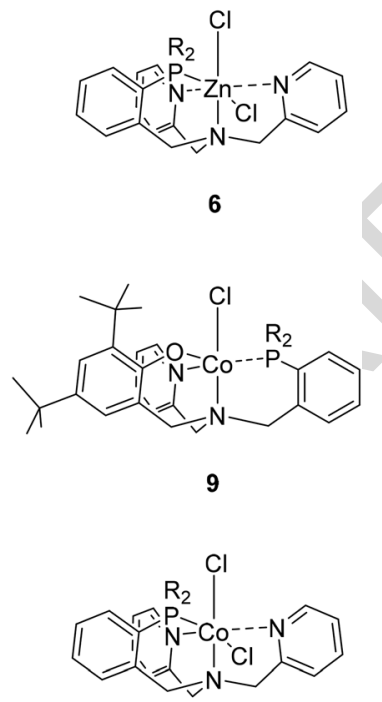

12

Fig. 7 Complexes 1-12 ( $=\mathrm{Ph})$

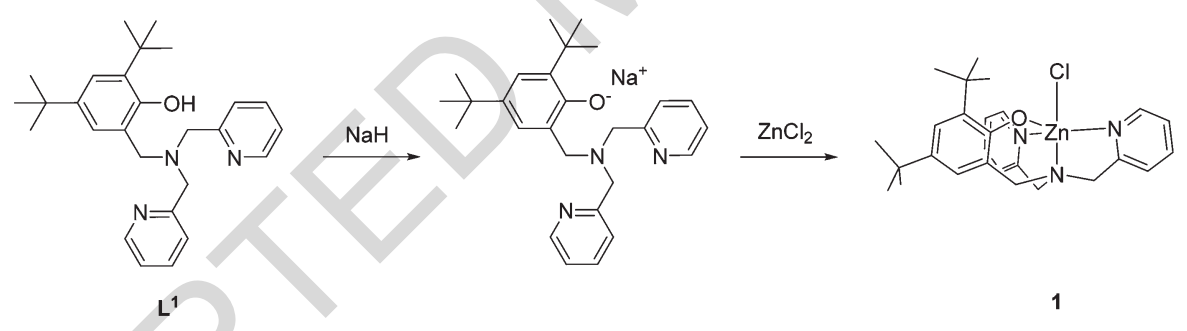

Scheme 1 Synthesis of 1.

symmetry on the NMR timescale. As further supported by the solid state structure of 2 (vide infra), these observations are consistent with both pyridyl groups coordinated onto the metal centre. The same features are also observed for $\mathbf{L}^{2}$ and $\mathbf{L}^{3}$ coordinated zinc complexes (see the Experimental section).

In the ${ }^{1} \mathrm{H}$ NMR of complex 5 (Fig. 9), all the signals, especially the benzylic $\mathrm{CH}_{2}$, are broadened singlets, suggesting a fluxional structure, probably due to the weak interaction between the zinc and the phosphorus atoms; the small coordination induced shifts $\Delta \delta{ }^{31} \mathrm{P}$ (complex-free ligand) are 4.2, 0 and $-2.5\left(\delta{ }^{31} \mathrm{P}\left(\mathbf{L}^{5}\right)=-16.3 \mathrm{ppm} ; \delta{ }^{31} \mathrm{P}(5)=-11.1,-16.3\right.$, $-18.8 \mathrm{ppm}$ ), and support weak interactions of two of the phosphorus atoms with the zinc metal centre. Variable-temperature NMR spectroscopy of complex 5 in $\mathrm{CDCl}_{3}$ revealed decoalescence of the resonances upon lowering the temperature, eventually resulting in the observation of individual resonances for two $\mathrm{NCH}_{2}$-phosphine groups at $-30^{\circ} \mathrm{C}$. These observations are also consistent with only two of the phosphine groups coordinated onto the metal centre and fast exchange of the coordinated and free phosphine groups on the NMR timescale at relatively high temperature. The enhanced steric flexibility within $\mathbf{L}^{\mathbf{5}}$, originating from the presence of less donating phosphino groups, and the corresponding more opened coordination sphere at the metal centre might be responsible for the formation of a mixture of monomeric (5) and dimeric/ oligomeric species. ${ }^{11}$ In ${ }^{31} \mathrm{P}$ NMR spectra, one shielded and one deshielded signals compared to the free ligand signal are observed (see the Experimental section). The same situation, that is, a coordinated pyridyl/phosphino group and a free pyridyl/phosphino group, can be envisioned for the other metal complexes. Alternatively, we cannot rule out that all $\sigma$-donor groups are coordinated to the metal centre in 1-12, 
- $\mathrm{CH}_{2}$ picolyl arms

- $\mathrm{CH}_{2}$ phenol arm

- H pyridine

\section{$\left[L^{1}\right] \mathrm{H}$}
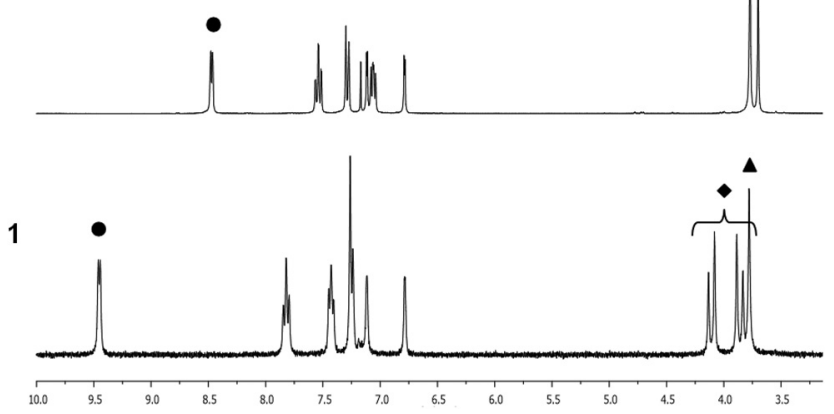

Fig. $8{ }^{1} \mathrm{H}$ NMR spectra of pro-ligand $\left[\mathrm{L}^{1}\right] \mathrm{H}$ (up) and 1 (down) $\left(\mathrm{CDCl}_{3}\right.$, $25^{\circ} \mathrm{C}, 300 \mathrm{MHz}$ ).

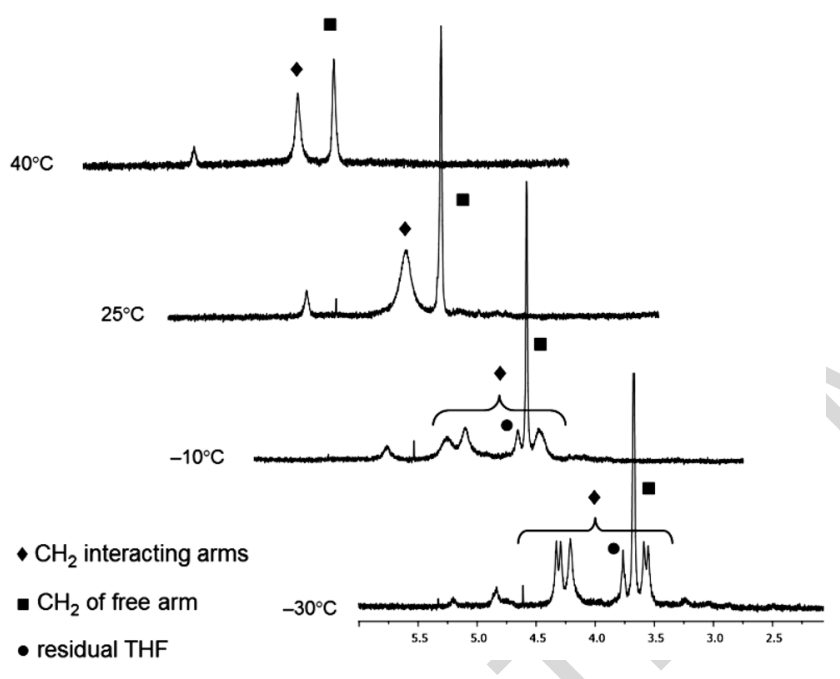

Fig. 9 Variable temperature ${ }^{1} \mathrm{H}$ NMR experiment for $\left(\mathrm{L}^{5}\right) \mathrm{ZnCl}_{2} \quad$ (5); benzylic region $\left(400 \mathrm{MHz}\right.$, from $40{ }^{\circ} \mathrm{C}$ to $\left.-30{ }^{\circ} \mathrm{C}, \mathrm{CDCl}_{3}\right)$.

either in a symmetric or a dissymmetric fashion. In the case of nitrogen containing pro-ligand homologues, observation of the exchange mechanism between two pyridine arms on the zinc atom was reported for a $\left(\mathrm{N}_{4}\right) \mathrm{ZnCl}_{2}$ system $\left(\mathrm{N}_{4}=N-[(2-\right.$ pyridyl)methyl]-2,2'-dipyridylamine). ${ }^{16}$ In addition, as already observed by Kol in zinc complexes supported by aminophenolate ligands bearing 2-methoxyethyl arms, one arm can be tightly coordinated and the other one can be weakly coordinated onto the metal centre. ${ }^{17}$

The crystal structure of complex 2 was determined by X-ray diffraction studies. Complex 2 is monomeric in the solid state and features a five-coordinated zinc centre in a distorted bipyramidal trigonal geometry (Fig. 10). Furthermore, the geometric parameter $\tau$ defined by Addison and Reedijk is 0.80, which implies that the coordination geometry is best described as a distorted bipyramidal trigonal. ${ }^{18}$ Consistent with the NMR

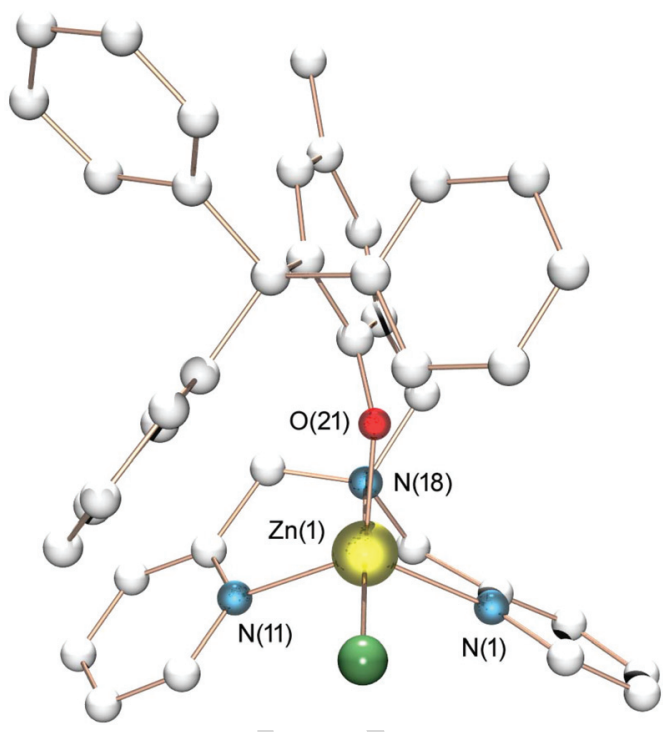

Fig. 10 Molecular structure of 2 (hydrogen atoms and solvent molecules are omitted for clarity).

observations in solution for complex 1 (vide supra), the two pyridyl groups per molecule are coordinated, together with the $\mathrm{N}$ and $\mathrm{O}$ atoms of the ligand, forming one six-membered metallacycle and two five-membered metallacycles. Therefore, though potentially tridentate in solution, the tripodal aminophenolate is actually tetradentate. The coordination sphere is completed by the chloro ligand. The $\mathrm{Zn}-\mathrm{O}$ and $\mathrm{Zn}-\mathrm{N}$ bond distances fall in normal ranges for similar complexes. ${ }^{11}$

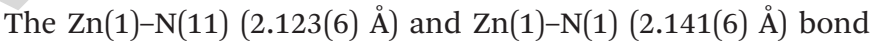
distances are comparable, likely reflecting a relatively strong $\sigma$-donor effect of the pyridyl groups. The six-membered metallacycle adopts a boat conformation, as observed in other trisaminophenolate zinc complexes.

\section{Paramagnetic NMR spectroscopy of the cobalt complexes}

The NMR of paramagnetic species has been extensively studied over the past few decades. ${ }^{19-22}$ In diamagnetic molecules, the chemical shift arises from the orbital shift linked to the shield constant. In paramagnetic molecules, a hyperfine shift is added modifying the observed chemical shift. Even though the presence of a paramagnetic centre in the molecule modifies the NMR spectra, some information can still be extracted from NMR experiments. ${ }^{23}$ Despite the acceleration of relaxation processes, the integration of NMR signals is still linked to the number of nuclei involved in the resonance. ${ }^{24}$ Moreover, by setting the parameters to the correct values, recording of $2 \mathrm{D}$ NMR spectra is possible, allowing seeing the correlations between nuclei spin magnetic moments.

As expected, the cobalt(II) complex $\left(\mathrm{L}^{6}\right) \mathrm{CoCl}_{2} 12$ is paramagnetic, displaying broad signals in its ${ }^{1} \mathrm{H}$ and ${ }^{31} \mathrm{P}$ NMR spectra. ${ }^{25}$ The ${ }^{1} \mathrm{H}$ NMR spectrum displays ten resonances over the fourteen expected for a $C_{\mathrm{S}}$ symmetrical complex (Fig. 11). The most down-fielded resonances at 131.5, 64.3 and 43 ppm can be easily attributed to protons on the pyridine cores as 


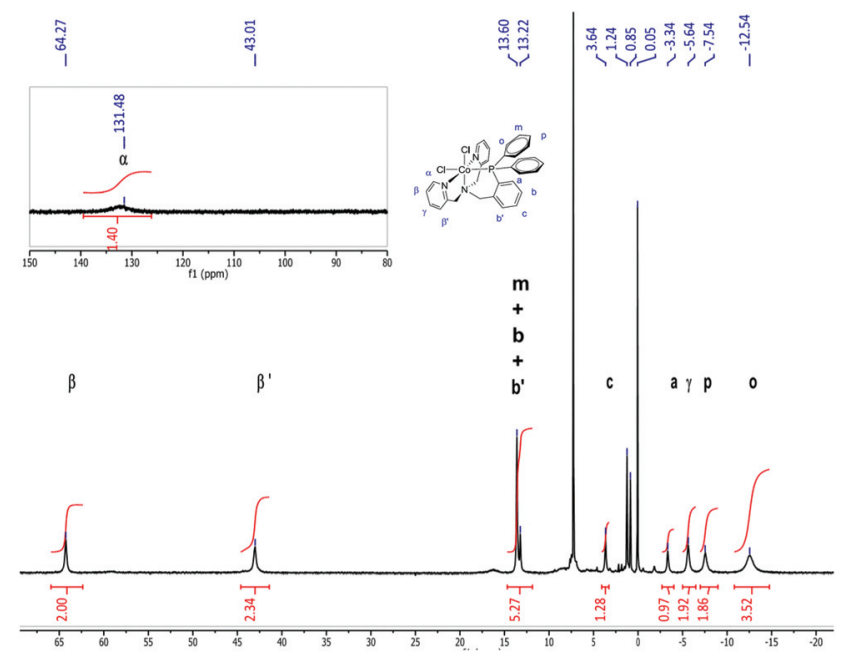

Fig. $11{ }^{1} \mathrm{H}$ NMR spectrum of complex $12\left(\mathrm{CDCl}_{3}, 25^{\circ} \mathrm{C}, 300 \mathrm{MHz}\right)$.

often attributed in similar iron(II) complexes (Table 2). ${ }^{26}$ The COSY experiment with the $\{43.0 \mathrm{ppm} ;-5.6 \mathrm{ppm}\}$ correlation gives the last signal for the pyridines cycle (Fig. 1S†). The attribution of the different signals is allowed by the correlation between relaxation times and the distance to the paramagnetic centre. The broadest peak at $131.5 \mathrm{ppm}$ corresponds to the nucleus in $\alpha$ position. The two signals at $64.3 \mathrm{ppm}$ and $43.0 \mathrm{ppm}$ can be attributed to the $\beta$ and $\beta^{\prime}$ protons, respectively. The phenyl groups of the triarylphosphine are easily assigned with the peak integration. Those aromatic cycles are the only possibility to have four or two equivalent protons. The protons in ortho position are the closest to the metal centre and thus are the most shielded and shifted to $-12.5 \mathrm{ppm}$. In addition the meta protons resonate at $13.6 \mathrm{ppm}$ and the two para protons at $-7.5 \mathrm{ppm}$. The relative position of these signals is different from the position of the pyridine proton signals, which can be explained by the difference of the coordination mode. The direct bonding through the nitrogen donor atom increases the residual electronic spin density on the pyridine atoms yielding a stronger Fermi contact interaction. Finally, for the last aromatic ring, 4 non-equivalent protons are identified. The proton $a$ in ortho position is assigned to the $-3.3 \mathrm{ppm}$ signal, the broadest and quickest relaxing. The other signals are attributed following the same pattern as the two phenyl rings. As protons on all aromatic cycles are subjected to a strong paramagnetic shift, all donor atoms are coordinated to the metal centre. In this spectrum the benzylic protons are not detected either due to their fast relaxation at the NMR timescale or due to an excessive peak width.



Fig. $12{ }^{1} \mathrm{H}$ NMR spectrum of complex $7\left(\mathrm{CDCl}_{3}, 25^{\circ} \mathrm{C}, 300 \mathrm{MHz}\right)$.

The description of the previous complex enables a faster interpretation of other cobalt(II) complexes with the same framework. In particular, the ${ }^{1} \mathrm{H}$ NMR spectrum of 7 displays the same paramagnetic pattern (Fig. 12). The pyridine proton signals are observed in the same range as in $\mathbf{1 2}$. The main difference concerns the two aromatic protons of the phenolate ring which resonate at $46.3 \mathrm{ppm}$ and $29.3 \mathrm{ppm}$. Like previously, the most down-fielded signal is attributed to the $b$ position. The greater paramagnetic shift of these protons is explained by the increased electronic spin density on the ring as there are fewer rings on which it can be delocalized. Even if they are in the diamagnetic region, the $t$ Bu protons are less shielded than in the free protonated ligand. The protons in ortho position appear as a broad signal at $3.45 \mathrm{ppm}$ and the other ones as a sharper signal at $3.75 \mathrm{ppm}$.

As a $\mathrm{d}^{7}$ ion, the cobalt centre can either be in a low spin configuration $(S=1 / 2)$ or a high spin configuration $(S=3 / 2)$. A change of the spin configuration in a given geometry has a strong influence on the ionic radius. ${ }^{27}$ The magnetic moment can be directly measured by SQUID experiments or by the NMR Evan's method. ${ }^{28,29}$ Therefore, the magnetic moment of complex 12 was measured with both techniques and gave, respectively, $\mu_{\text {eff }}=4.0 \mu_{\mathrm{B}}$ and $\mu_{\text {eff }}=3.9 \mu_{\mathrm{B}}$. As the complex is not in the same state for these two methods, the results can differ due to different accessible configurations in the liquid state. Nevertheless, both methods indicate a cobalt in its high spin configuration. ${ }^{30}$ The magnetic moment of 7 , determined using

Table 2 Chemical shift, spin-lattice relaxation time, half-height width and integration of the ${ }^{1} \mathrm{H} \mathrm{NMR}$ spectrum of 12 in $\mathrm{CDCl}_{3}$

\begin{tabular}{llllllllll}
\hline & $\alpha$ & $\beta$ & $\beta^{\prime}$ & $m+b$ & $b^{\prime}$ & $c$ & $a$ & $\gamma$ & \multicolumn{1}{c}{$c$} \\
\hline$\delta(\mathrm{ppm})$ & 131.5 & 64.3 & 43.0 & 13.6 & 13.2 & 3.6 & -3.3 & -5.6 & -7.5 \\
$T_{1}(\mathrm{~ms})$ & 0.4 & 14.4 & 7.6 & 26.1 & 35.2 & 38.5 & 10.2 & 21.2 & 49 \\
$\nu_{1 / 2}(\mathrm{~Hz})$ & 800 & 75 & 60 & 30 & 40 & 25 & 45 & 65 & 1.3 \\
Integration & 2 & 2 & 2 & 5 & 1 & 1 & 1 & 2.5 \\
\end{tabular}


Evans' method in solution, was found to be $4.8 \mu_{\mathrm{B}}$, consistent with a $\mathrm{d}^{7}$ metal centre having three unpaired electrons.

\section{Reactivity towards rac-lactide}

A range of catalytic species have been employed to mediate the polymerization of LA. ${ }^{31}$ However, in spite of great efforts in this field, there is still a demand for highly active, nontoxic, and stable complexes that can be easily handled. In this regard, ROP catalysts have not been widely investigated in bulk polymerizations, although there is significant interest in using metal-based catalysts that are active in bulk monomers. Indeed, bulk polymerizations are industrially attractive and compliant with the principles of green chemistry. ${ }^{32}$ For instance, Feijen et al. demonstrated that a chiral Schiff-base (SALEN type) aluminium complex based on $(R, R)$-cyclohexanediamine is an isoselective initiator for the polymerization of racemic lactide at $130{ }^{\circ} \mathrm{C} .{ }^{33}$ Interestingly, this catalytic system proceeded under solvent free conditions, and gave high-yield reactions, controlled molecular weights and narrow polydispersities. Unfortunately, this aluminium-based initiator was not sufficiently active to be industrially viable, as two days were necessary to convert 200 eq. of lactide. ${ }^{33}$ Also, Hillmyer reported a detailed study of analogous $\mathrm{Zn}, \mathrm{Mg}$, and $\mathrm{Co}$ dinuclear complexes, showing that the dizinc complex is the most active of the series; in melt lactide at $140{ }^{\circ} \mathrm{C}$, more than 4000 eq. of lactide were converted by the dinuclear zinc complex to produce atactic polylactide with low molecular weight control $\left(M_{\mathrm{n}} 57 \mathrm{~kg} \mathrm{~mol}{ }^{-1} ; M_{\mathrm{w}} / M_{\mathrm{n}} 2.6\right) .{ }^{34}$ Only one other example of cobalt-based $\left[\mathrm{Co}(\mathrm{OAr})_{3}\right]\left[\mathrm{Na}(\mathrm{THF})_{6}\right]$ complexes was reported for melt lactide polymerization with moderate activity and control. ${ }^{35}$

As noted earlier, a great challenge in the production of PLA is the catalytic polymerization of lactide, thus optimizing productivity of the metal-based species and minimizing contamination of polymer with metal residues. In this regard, we were interested in investigating the catalytic behaviour of our chloride complexes for lactide polymerization in combination with an alcohol under solvent free conditions. Representative results observed in these polymerizations using benzyl alcohol as a reversible transfer agent are collected in Table 3. All complexes ${ }^{36}$ were tested for ring-opening polymerization of rac-lactide at $130{ }^{\circ} \mathrm{C}$ under solvent free conditions. As control experiments the homoleptic zinc and cobalt dichloride precursors were tested in the presence or absence of alcohol for the ring-opening polymerization of rac-lactide. By contrast to previous observations, ${ }^{37}$ we observed activity in the case of zinc dichloride in the presence or absence of alcohol at $130{ }^{\circ} \mathrm{C}$, even if the polymerization rate and control were low (Table 3, entry 1). However, $\mathrm{CoCl}_{2}$ is inactive for the ROP of lactide in bulk at $130{ }^{\circ} \mathrm{C}$ (entry 2). Generally, in the absence of alcohol, the $\mathrm{Zn}$ complexes (Table 3, entries 4, 7, 9 and 11) and the Co complexes (Table 3 , entry 17 ) gave also modest reactivities and controls.

Notably, the combination based on zinc complex $\mathbf{1}$ and 10 equiv. of benzyl alcohol readily polymerized 130 equiv. of racLA in $3 \mathrm{~h}$ at $130{ }^{\circ} \mathrm{C}$, leading to PLA with an experimentally determined $M_{\mathrm{n}}$ value in close agreement with the calculated one (entry 3). Interestingly, for most of the systems tested, we observed that in the presence of an excess of benzyl alcohol (10 equiv.), polymers with narrow polydispersities and controlled molecular weights, which could be predicted from the monomer-to-alcohol ratio, were obtained. ${ }^{38}$ Depending on the ligand framework, the zinc initiator is not always more active than its Co analogue. For instance, the cobalt complex 7 (entry 13), which bears ligand $\mathbf{L}^{\mathbf{1}}$ with a tert-butyl group in the ortho position of the phenolate, is as active as the $\mathrm{Zn}$ derivative $\mathbf{1}$ (entry 3). When the ortho-substituent is a bulkier $\mathrm{CPh}_{3}$ substituent, the corresponding zinc complex 2 is much more active and

Table 3 Polymerization of lactide using Co and Zn complexes ${ }^{a}$

\begin{tabular}{|c|c|c|c|c|c|c|c|c|c|}
\hline Entry & Initiator & {$[\mathrm{LA}] /[\mathrm{I}]$} & {$[\mathrm{BnOH}] /[\mathrm{I}]$} & Time (h) & Conv. $^{b}(\%)$ & $M_{\mathrm{n}, \text { calc. }}{ }^{c}\left(\mathrm{~g} \mathrm{~mol}^{-1}\right)$ & $M_{\mathrm{n}}^{d}\left(\mathrm{~g} \mathrm{~mol}^{-1}\right)$ & $M_{\mathrm{w}} / M_{\mathrm{n}}{ }^{d}$ & $\operatorname{TOF}\left(\mathrm{h}^{-1}\right)$ \\
\hline 1 & $\mathrm{ZnCl}_{2}$ & 1000 & 10 & 3 & 11 & $\mathrm{ND}^{e}$ & ND & ND & 37 \\
\hline 2 & $\mathrm{CoCl}_{2}$ & 1000 & 10 & 3 & 0 & ND & ND & ND & 0 \\
\hline 3 & 1 & 1000 & 10 & 3 & 13 & 1800 & 1100 & 1.06 & 43 \\
\hline 4 & 2 & 1000 & - & 0.25 & 28 & 40300 & 41000 & 2.02 & 1120 \\
\hline 5 & 2 & 1000 & 10 & 0.25 & 75 & 10800 & 10500 & 2.00 & 3000 \\
\hline 6 & 2 & 5000 & 10 & 0.25 & 44 & 31700 & 17000 & 1.71 & 8800 \\
\hline 7 & 3 & 1000 & - & 2 & 27 & 38800 & 8200 & 1.32 & 135 \\
\hline 8 & 3 & 1000 & 10 & 2 & 83 & 11900 & 11300 & 1.16 & 415 \\
\hline 9 & 4 & 1000 & - & 3 & 5 & ND & ND & ND & 16 \\
\hline 10 & 4 & 1000 & 10 & 3 & 66 & 9300 & 6700 & 1.05 & 218 \\
\hline 11 & 5 & 1000 & - & 1 & 12 & 17300 & 20800 & 1.22 & 120 \\
\hline 12 & 5 & 1000 & 10 & 1 & 77 & 11000 & 12300 & 1.38 & 770 \\
\hline 13 & 7 & 1000 & 10 & 3 & 13 & ND & ND & ND & 43 \\
\hline 14 & 8 & 1000 & 10 & 3 & 45 & 6400 & 5000 & 1.21 & 150 \\
\hline 15 & 9 & 1000 & 10 & 3 & 26 & 3700 & 2300 & 1.07 & 86 \\
\hline 16 & 10 & 1000 & 10 & 3 & 10 & ND & ND & ND & 33 \\
\hline 17 & 11 & 1000 & - & 3 & 7 & ND & ND & ND & 23 \\
\hline 18 & 11 & 1000 & 10 & 3 & 60 & 8600 & 7300 & 1.08 & 200 \\
\hline
\end{tabular}

${ }^{a}$ Polymerization was performed in melt rac-lactide at $130{ }^{\circ} \mathrm{C} .{ }^{b}$ Conversion was determined by ${ }^{1} \mathrm{H}$ NMR (integration of the methyl resonances of LA ad PLA $) .{ }^{c} M_{\mathrm{n}, \text { calc }}=144.00 \times([\mathrm{LA}] /[\mathrm{I}]) \times$ conv. $/([\mathrm{BnOH}] /[\mathrm{I}]) .{ }^{d} M_{\mathrm{n}}$ and $M_{\mathrm{w}} / M_{\mathrm{n}}$ of polymer determined by SEC-RI in THF at RT using polystyrene standards and $M_{\mathrm{n}}$ corrected by the Mark-Houwink parameter $(0.58) .{ }^{e}$ Not determined. 
exhibits the highest activity observed in this study with a TOF up to $8800 \mathrm{~h}^{-1}$ (entry 6). However, introduction of a bulkier ortho-substituent in the $\mathrm{N}_{3} \mathrm{O}$ ligand also decreases the control of polymerization $\left(M_{\mathrm{n}}\right.$ shorter than the expected one and PDI broadened). Remarkably, as opposed to the chloro metal complexes that were previously evaluated under similar conditions, the zinc complex 2 is significantly more efficient. ${ }^{37}$ Indeed, these data lie in the same range as the highest activities obtained with unstable catalytic systems, the major difference being that the present zinc catalytic system is much easier to handle. ${ }^{37}$

The phosphorus atom is a soft donor and has a weak interaction with the zinc metal centre. Therefore, by replacing a pyridine arm by a phosphine arm, the metal centre is more accessible and more electrophilic. This is evidenced by the ROP of LA by an increased polymerization rate for 3 compared to 1 (entries 3 and 8). Also, the replacement of a pyridyl group in $\mathbf{4}$ by a phosphine group in $\mathbf{5}$ increases the activity of the initiators from a TOF of 218 to $770 \mathrm{~h}^{-1}$ respectively (entries 10 and 12). We assume that, since the phosphine ligand $\mathbf{L}^{\mathbf{5}}$ is more labile than the ligand $\mathbf{L}^{\mathbf{4}}$, the environment around the zinc metal centre is less hindered, resulting in better activity. Similar to what was obtained in the case of $\mathrm{N}_{3} \mathrm{O}$ ligands, PDI are slightly broadened (from 1.05 to 1.4 ) as the activity increases. In the case of neutral $\mathrm{N}_{m} \mathrm{P}_{n}$ ligand derivatives, the zinc is bonded to two chloride atoms, meaning that in the presence of benzyl alcohol, the propagation of two polymer chains can occur. However the molecular weights of the polymer obtained for the zinc dichloride complexes 4 and $\mathbf{5}$ suggest that only one polymeric chain is formed per metal atom.

Among the cobalt derivatives, complexes $\mathbf{8}$ and 11 exhibit good activity and excellent control for ROP of lactide at $130{ }^{\circ} \mathrm{C}$ (entries 14 and 18). As already observed for zinc complexes, the cobalt complex 8 (entry 14 ), which bears ligand $\mathbf{L}^{2}$ with a trityl group in the ortho position of the phenolate, is much more active than the Co analog 7 bearing tert-butyl-substituted ligand $\mathbf{L}^{\mathbf{1}}$ (entry 13). The poor reactivity of complex $\mathbf{1 0}$ (entry 16) might arise from the low solubility of the corresponding pre-catalyst. Overall, such performances compare well with those reported for some related, efficient cobalt and zinc chloro systems. ${ }^{5}$ Finally, a somehow disappointing feature of these systems remains the absence of stereocontrol achieved in the ROP of racemic lactide, whatever the substituents on the ligands and the nature of the donor fragments.

\section{Conclusion}

We have reported a new series of zinc and cobalt chloride complexes supported by readily available tripodal ligands. The corresponding versatile systems enable the production of large quantities of polymer with small amounts of a catalyst, optimizing productivity and thus minimizing the contamination of polymer with metal residues. These organometallic catalysts, which are easily synthesized, are thermally robust, thus allowing their use under bulk conditions. These results suggest a number of new avenues for biodegradable polymers. Indeed the discovery of efficient and productive organometallic catalysts for the synthesis of biodegradable polymers is a crucial requirement for a sustainable growth of the chemical industry.

\section{Experimental section}

\section{General considerations}

All reactions were carried out under an argon atmosphere using Schlenk techniques or a glove box ( $<1 \mathrm{ppm} \mathrm{O}_{2},<2 \mathrm{ppm}$ $\mathrm{H}_{2} \mathrm{O}$ ). Tetrahydrofuran, pentane and toluene were dried with a solvent purification system (PureSolv, Innovative Technology, Inc.) and degassed by freeze pump thaw cycles prior to use. Anhydrous dichloroethane, etheral solution of $\mathrm{HCl}(1 \mathrm{M})$, 2-picolylamine, 3,5-di-tert-butyl-4-hydroxybenzaldehyde, and sodium triacetoxyborohydride (stored in a glove box) were purchased from Aldrich and used as received. Anhydrous cobalt dichloride $\left(\mathrm{CoCl}_{2}\right)$ and zinc dichloride $\left(\mathrm{ZnCl}_{2}\right)$ were purchased from Strem Chemicals. 2-Diphenylphosphinobenzaldehyde was prepared by a previously described method. ${ }^{39}$ Deuterated solvents from Eurisotop were dried and degassed by freeze pump thaw cycles (deuterated chloroform was distilled over phosphorus pentoxide, and deuterated benzene was distilled over sodium/benzophenone). NMR spectra were recorded on a Bruker Avance 300, Avance 400 or AM-500 MHz spectrometer (at the Ecole Nationale Supérieure de Chimie de Paris and at University of Caen). Chemical shifts are reported in ppm and coupling constants $J$ in hertz. NMR spectra were calibrated using residual ${ }^{1} \mathrm{H}$ and ${ }^{13} \mathrm{C}$ resonances of deuterated solvents. External calibration for ${ }^{31} \mathrm{P}$ was made with $85 \% \mathrm{H}_{3} \mathrm{PO}_{4}$ as a standard. Assignment of signals was made from ${ }^{13} \mathrm{C}\left\{{ }^{1} \mathrm{H}\right\}\left\{{ }^{31} \mathrm{P}\right\}$, $2 \mathrm{D}{ }^{1} \mathrm{H}-{ }^{1} \mathrm{H}$ COSY, ${ }^{1} \mathrm{H}-{ }^{13} \mathrm{C}$ HMQC and HMBC NMR experiments. The paramagnetic spectrum sequence was as follows: a $\pi / 6$ pulse followed by a $550 \mathrm{~ms}$ acquisition and a $2 \mathrm{~s}$ delay for a spectrum width of $220 \mathrm{ppm}$ with $64 \mathrm{k}$ points. After the FFT, a $0.3 \mathrm{~Hz}$ filter is applied. For the $T_{1}$ measurements, the inversion-recovery sequence was used: $\pi$ pulse, variable delay $\tau, \pi / 2$ pulse and acquisition. The paramagnetic COSY 45 used an acquisition time of $32 \mathrm{~ms}$ and a delay of $1 \mathrm{~s}$ with TD1 $=512$, TD2 $=2048$ with an accumulation of 64 scans. For the paramagnetic complexes, numbers in brackets are the peak halfwidth in $\mathrm{Hz}$ and the number of protons for this signal. X-ray diffraction analyses were performed at the Laboratoire de Diffractométrie X, UMR 6226, CNRS-Université de Rennes 1 (France). Elemental analyses $(\mathrm{C}, \mathrm{H}, \mathrm{N})$ were performed at the Elemental Analysis Service of the London Metropolitan University (UK) and are the average of two independent determinations. High-resolution mass spectra were performed at Institut Parisien de Chimie Moléculaire, UMR CNRS 7201, University Pierre et Marie Curie (France). Size exclusion chromatography (SEC) of polymers was performed in THF at $35^{\circ} \mathrm{C}$ using an Agilent 1260 Infinity Series GPC (ResiPore $3 \mu \mathrm{m}, 300 \times$

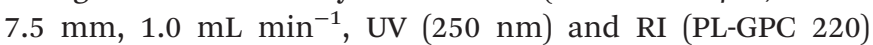


detectors). The number average molecular masses $\left(M_{\mathrm{n}}\right)$ and polydispersity index $\left(M_{\mathrm{w}} / M_{\mathrm{n}}\right)$ of the polymers were calculated with reference to universal calibration vs. polystyrene standards (limits $M_{\mathrm{w}}=200$ to $400000 \mathrm{~g} \mathrm{~mol}^{-1}$ ). SQUID measurements were recorded on a MPMS-XL7 apparatus. UV-visible spectra were recorded on a Safas-Monaco spectrometer from $250 \mathrm{~nm}$ to $1000 \mathrm{~nm}$ with $2 \mathrm{~nm}$ steps. Molar conductivities of freshly prepared $10^{-3}$ mol $\mathrm{L}^{-1}$ solutions of zinc and cobalt complexes in DMF were measured on a CDM 210 conductivity meter.

\section{General procedure: synthesis of $N$-(2-hydroxybenzyl)- $N, N$-bis- (2-pyridylmethyl)amine proligands $\left(\mathrm{N}_{3} \mathrm{O}\right) \mathrm{H}$}

Into a solution of di-(2-picolyl)amine ( $1 \mathrm{~g}, 5 \mathrm{mmol})$ and appropriate salicylaldehyde $(5.5 \mathrm{mmol})$ in 1,2-dichloroethane $(12.5 \mathrm{~mL})$, sodium triacetoxyborohydride $(1.7 \mathrm{~g}, 8 \mathrm{mmol})$ was added. The mixture was stirred overnight at room temperature, and water $(15 \mathrm{~mL})$ was poured into the solution and stirred for another $30 \mathrm{~min}$. The organic phase was separated from aqueous phase and dried over magnesium sulfate $\left(\mathrm{MgSO}_{4}\right)$. The solvent was removed under vacuum and the final product was purified by recrystallisation in cold methanol.

\section{$N$-(3,5-Ditert-butyl-2-hydroxybenzyl)- $N, N$-bis(2-pyridylmethyl)-} amine $\left(\mathrm{N}_{3} \mathrm{O}^{t \mathrm{Bu}}\right) \mathrm{H}\left(\left[\mathrm{L}^{1}\right] \mathrm{H}\right)$ (Fig. 13)

White solid with $85 \%$ yield. ${ }^{1} \mathrm{H}$ NMR $\left(300 \mathrm{MHz}, 25{ }^{\circ} \mathrm{C}, \mathrm{CDCl}_{3}\right)$ : $\delta=8.47(\mathrm{~d}, J=4.2 \mathrm{~Hz}, 2 \mathrm{H}, \mathrm{H} 1), 7.53(\mathrm{t}, J=4.2 \mathrm{~Hz}, 2 \mathrm{H}, \mathrm{H} 2), 7.29$ (d, $J=4.8 \mathrm{~Hz}, 2 \mathrm{H}, \mathrm{H} 4), 7.13$ (d, $J=2.4 \mathrm{~Hz}, 1 \mathrm{H}, \mathrm{H} 9), 7.08$ (m, 2H, H3), 6.79 (d, J = 2.4 Hz, 1H, H11), 3.80 (s, 4H, H6), 3.73 (s, 2H, H7), 1.38 (s, 9H, H17), 1.19 (s, 9H, H14); ${ }^{13} \mathrm{C}$ NMR (75 MHz, $25{ }^{\circ} \mathrm{C}, \mathrm{CDCl}_{3}$ ): $\delta=158.1$ (C5), 153.8 (C13), 149.0 (C1), 140.4 (C8), 136.6 (C4), 135.6 (C12), 124.5 (C9), 123.6 (C2), 123.1 (C11), 122.2 (C3), 121.7 (C10), 56.5 (C6), 58.3 (C7), 34.7 (C16), 34.1 (C15), 31.7 (C17), 29.7 (C14).

$N$-(3-Trityl-5-methyl-2-hydroxybenzyl)- $N, N$-bis(2-pyridylmethyl)amine $\left(\mathrm{N}_{3} \mathrm{O}^{\mathrm{CPh} 3}\right) \mathrm{H}\left(\left[\mathrm{L}^{2}\right] \mathrm{H}\right)$ (Fig. 13)

White solid with $75 \%$ yield. ${ }^{1} \mathrm{H}$ NMR $\left(300 \mathrm{MHz}, 25^{\circ} \mathrm{C}, \mathrm{CDCl}_{3}\right)$ : $\delta=8.32(\mathrm{~d}, J=4 \mathrm{~Hz}, 2 \mathrm{H}, \mathrm{H} 1), 7.42\left(\mathrm{t}-\mathrm{d}, J_{1}=4 \mathrm{~Hz}, J_{2}=1.8 \mathrm{~Hz}\right.$, 2H, H2), 7.30-6.95 (m, 17H, H3, H14), 6.85 (d, $J=9 \mathrm{~Hz}, 2 \mathrm{H}$,

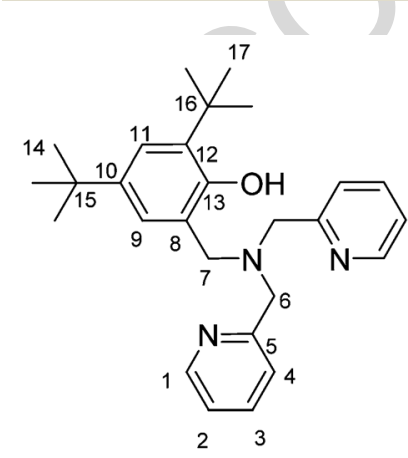

$\left[\mathrm{L}^{1}\right] \mathrm{H}$

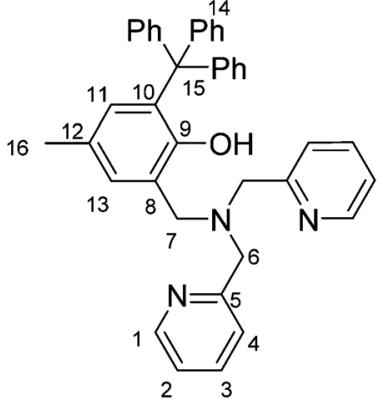

$\left[L^{2}\right] \mathrm{H}$
Fig. $13\left[\mathrm{~L}^{1}\right] \mathrm{H}$ and $\left[\mathrm{L}^{2}\right] \mathrm{H}$ with position numbering.
H4), 6.82 (d, $J=1.8 \mathrm{~Hz}, 1 \mathrm{H}, \mathrm{H} 13), 6.74$ (d, $J=1.8 \mathrm{~Hz}, 1 \mathrm{H}, \mathrm{H} 11)$, 3.66 (s, 2H, H7), 3.59 (s, 4H, H6), 2.08 (s, 3H, H16); ${ }^{13} \mathrm{C}$ NMR (75 MHz, $25{ }^{\circ} \mathrm{C}, \mathrm{CDCl}_{3}$ ): $\delta=157.5$ (C5), 153.8 (C9), 148.7 (C1), 146.2 (C4), 136.8 (C14), 133.8 (C8), 131.3 (C14), 131.0 (C10), 129.6 (C12), 126.9 (C14), 126.5 (C13), 125.2 (C14), 123.8 (C2), 122.3 (C11), 122.1 (C3), 63.3 (C15), 58.6 (C7), 57.9 (C6), 20.9 (C16); HRMS exact mass calcd for $[\mathrm{M}+\mathrm{H}]^{+} 601.3342$, found 601.3330 .

$N$-(3,5-Ditert-butyl-2-hydroxybenzyl)- $N$-(2-(diphenylphosphino)benzyl)- $N$-bis(2-pyridylmethyl)amine $\left(\mathrm{N}_{2} \mathrm{PO}\right) \mathrm{H}\left(\left[\mathrm{L}^{3}\right] \mathrm{H}\right)$ : two steps of reductive amination (Fig. 14)

A solution of 3,5-ditert-butyl-4-hydroxybenzaldehyde (2.38 g, $10.1 \mathrm{mmol}$ ) and 2-(aminomethyl)pyridine (1 g, $9.2 \mathrm{mmol}$ ) in methanol $(100 \mathrm{~mL})$ was stirred under reflux for $2 \mathrm{~h}$. The solution was cooled down to room temperature and sodium borohydride (1.74 g, $46 \mathrm{mmol}$ ) was added in small portions. After $\mathrm{NaBH}_{4}$ was completely dissolved, the solvent was removed under vacuum. Dichloromethane $(100 \mathrm{~mL})$ and water $(100 \mathrm{~mL})$ were added to the crude product and the mixture was stirred for $1 \mathrm{~h}$. The organic phase was washed two times more with water and dried over magnesium sulfate $\left(\mathrm{MgSO}_{4}\right)$. After removal of solvent, the product was further dried under vacuum for $24 \mathrm{~h}$. It was then dissolved in 1,2-dichloroethane (23 $\mathrm{mL}$ ) along with 2-diphenylphosphino-benzaldehyde (2.93 $\mathrm{g}, 10.1 \mathrm{mmol})$ and sodium triacetoxyborohydride (3.2 g, $14.7 \mathrm{mmol}$ ) was then added. The mixture was stirred overnight at room temperature, and water $(15 \mathrm{~mL})$ was poured into the solution to stir for another $30 \mathrm{~min}$. The organic phase was separated from aqueous phase and dried over magnesium sulfate $\left(\mathrm{MgSO}_{4}\right)$. The solvent was removed under vacuum and the final product was purified by recrystallization in cold methanol to give a white powder $(4.1 \mathrm{~g}, 6.9 \mathrm{mmol}, 75 \%) .{ }^{1} \mathrm{H} \mathrm{NMR}$ $\left(400 \mathrm{MHz}, 25{ }^{\circ} \mathrm{C}, \mathrm{CDCl}_{3}\right): \delta=10.67(\mathrm{~s}, 1 \mathrm{H}, \mathrm{OH}), 8.51(\mathrm{~d}, J=$ $3.6 \mathrm{~Hz}, 1 \mathrm{H}, \mathrm{H} 1), 7.62\left(\mathrm{t}-\mathrm{d}, J_{1}=5.7 \mathrm{~Hz}, J_{2}=1.2 \mathrm{~Hz}, 1 \mathrm{H}, \mathrm{H} 2\right), 7.57$ (m, 1H, H22), 7.27-7.38 (m, 8H) 7.17-7.26 (m, 5H), 7.10-7.16 (m, 2H), 6.80-6.87 (m, 2H), 3.93 (d, $J=2 \mathrm{~Hz}, 2 \mathrm{H}, \mathrm{H} 18), 3.76$ (s, 2H, H7), 3.74 (s, 2H, H6), 1.45 (s, 9H, H16), 1.26 (s, 9H, H14); ${ }^{13} \mathrm{C} \mathrm{NMR}\left(100 \mathrm{MHz}, 25{ }^{\circ} \mathrm{C}, \mathrm{CDCl}_{3}\right.$ ): $\delta=158.1$ (C5), 153.8 (C13), 149.0 (C1), 142.3 (d, $\left.J_{\mathrm{P}-\mathrm{C}}=23 \mathrm{~Hz}, \mathrm{C} 19\right), 140.5$ (C8), 136.8 (d, $\left.J_{\mathrm{P}-\mathrm{C}}=12 \mathrm{~Hz}, \mathrm{C} 25\right), 136.6$ (C3), 136.5 (C20), 135.5 (C12), 134.0

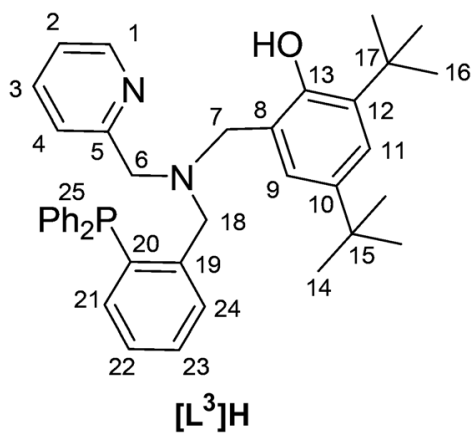

Fig. $14\left[\mathrm{~L}^{3}\right] \mathrm{H}$ with position numbering. 
$\left(\mathrm{d}, J_{\mathrm{P}-\mathrm{C}}=20 \mathrm{~Hz}, \mathrm{C} 25\right) 133.6(\mathrm{C} 21), 130.5\left(\mathrm{~d}, J_{\mathrm{P}-\mathrm{C}}=4 \mathrm{~Hz}, \mathrm{C} 24\right)$, 129.3 (C23), 128.8 (C25), 128.6 (d, $\left.J_{\mathrm{P}-\mathrm{C}}=7 \mathrm{~Hz}, \mathrm{C} 25\right), 127.7$ (C22), 124.4 (C11), 123.9 (C10), 123.0 (C9), 122.2 (C4), 121.9 (C2), 59.7 (C6), 58.1 (C7), 56.0 (d, $\left.J_{\mathrm{P}-\mathrm{C}}=22 \mathrm{~Hz}, \mathrm{C} 18\right), 35.0$ (C17), 34.1 (C15), 31.8 (C16), 29.7 (C14); ${ }^{31} \mathrm{P}\left\{{ }^{1} \mathrm{H}\right\}(120 \mathrm{MHz}$, $\left.25{ }^{\circ} \mathrm{C}, \mathrm{CDCl}_{3}\right): \delta=-16.2$. HRMS exact mass calcd for $[\mathrm{M}+\mathrm{H}]^{+}$ 562.2853 , found 562.2870 .

Synthesis of $N, N$-bis(2-(diphenylphosphino)benzyl)-1-(pyridin2-yl)methanamine $\left(\mathrm{N}_{2} \mathbf{P}_{2}, \mathrm{~L}^{4}\right)$ (Fig. 15)

A solution of 2-pyridinemethylamine $(0.279 \mathrm{~g}, 2.60 \mathrm{mmol})$ and 2-diphenylphosphino-benzaldehyde (1.50 g, $5.17 \mathrm{mmol})$ in degassed dichloroethane $(10 \mathrm{~mL})$ was stirred for a few minutes. Then, sodium triacetoxyborohydride $(1.42 \mathrm{~g}$, $6.72 \mathrm{mmol}$ ) was added. The heterogeneous mixture was stirred for $6 \mathrm{~h}$ at room temperature, until full conversion of the aldehyde (the disappearance of the aldehyde can be monitored by ${ }^{31} \mathrm{P}$ NMR). When the reaction was completed, the solvent was evaporated and the product was extracted with ethylacetate (AcOEt). The organic phase was washed with an aqueous saturated solution of $\mathrm{NaHCO}_{3}$ and the organic phase was separated and dried over magnesium sulfate $\left(\mathrm{MgSO}_{4}\right)$. The solvent was evaporated to give the crude product as a white solid foam. The solid was washed several times with pentane and dried. $\mathbf{L}^{\mathbf{4}}$ was obtained pure as a white powder $(1.53 \mathrm{~g}, 2.33 \mathrm{mmol}$, $90 \%)$. Single crystals for X-ray diffraction structure analysis were obtained by slow evaporation of a concentrated solution of $\mathbf{L}^{4}$ in acetone. ${ }^{1} \mathrm{H}$ NMR $\left(500 \mathrm{MHz}, 25{ }^{\circ} \mathrm{C}, \mathrm{CDCl}_{3}\right): \delta=8.34$ (m, 1H, H5), 7.70 (m, 2H, H9), $7.53(\mathrm{td}, J=7.71, J=1.9 \mathrm{~Hz}, 1 \mathrm{H}$, H3), 7.38 (brd, $J=7.71 \mathrm{~Hz}, 1 \mathrm{H}, \mathrm{H} 2), 7.29$ (m, 14H, H17, H16, H10), 7.18 (m, 8H, H15), 7.08 (m, 3H, H11, H4), 6.79 (m, 2H, H12), 3.83 (d, $\left.{ }^{4} J_{\mathrm{P}-\mathrm{H}}=2.1 \mathrm{~Hz}, 4 \mathrm{H}, \mathrm{H} 7\right), 3.65$ (s, 2H, H6); ${ }^{13} \mathrm{C}$ NMR (125 MHz, $25^{\circ} \mathrm{C}, \mathrm{CDCl}_{3}$ ): $\delta=159.9$ (C1), 148.7 (C5), 143.8 $\left(\mathrm{d}, J_{\mathrm{P}-\mathrm{C}}=22.0 \mathrm{~Hz}, \mathrm{C} 8\right), 136.8(\mathrm{~d}, J=11.0 \mathrm{~Hz}, \mathrm{C} 14), 136.2(\mathrm{C} 3)$, $136.1\left(\mathrm{~d}, J_{\mathrm{P}-\mathrm{C}}=14.5 \mathrm{~Hz}, \mathrm{C} 13\right), 133.9\left(\mathrm{~d}, J_{\mathrm{P}-\mathrm{C}}=19.6 \mathrm{~Hz}, \mathrm{C} 15\right)$, 133.3 (C12), 128.82 (C9), 128.80 (C10), 128.6 (C17), 128.5 (d, $\left.J_{\mathrm{P}-\mathrm{C}}=6.9 \mathrm{~Hz}, \mathrm{C} 16\right), 126.9$ (C11), 122.7 (C2), 121.7 (C4), 59.9 (C6), $56.1\left(\mathrm{~d}, J_{\mathrm{P}-\mathrm{C}}=23.4 \mathrm{~Hz}, \mathrm{C} 7\right) ;{ }^{31} \mathrm{P}\left\{{ }^{1} \mathrm{H}\right\}\left(200 \mathrm{MHz}, 25{ }^{\circ} \mathrm{C}\right.$, $\mathrm{CDCl}_{3}$ ): $\delta=-16.3$. Anal. calcd (\%) for $\mathrm{C}_{44} \mathrm{H}_{38} \mathrm{~N}_{2} \mathrm{P}_{2}$ : C, 80.47; H, 5.83; N, 4.27. Found: C, 80.37; H, 5.72; N, 4.18.

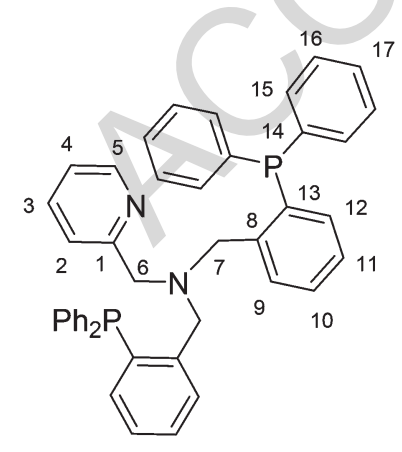

$\mathbf{L}^{4}$

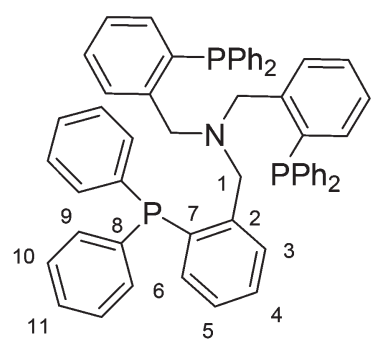

$\mathbf{L}^{5}$
Fig. $15 \quad \mathrm{~L}^{4}$ and $\mathrm{L}^{5}$ with position numbering.
Synthesis of tris(2-(diphenylphosphino)benzyl)amine $\left(\mathrm{NP}_{3}, \mathbf{L}^{5}\right)$ (Fig. 15)

A suspension of ammonium benzoate $(0.154 \mathrm{~g}, 1.11 \mathrm{mmol})$ in a solution of 2-diphenylphosphinobenzaldehyde $(1.00 \mathrm{~g}$, $3.45 \mathrm{mmol})$ in degassed dichloroethane $(10 \mathrm{~mL})$ was stirred for a few minutes. Then, sodium triacetoxyborohydride $(1.06 \mathrm{~g}$, $5 \mathrm{mmol}$ ) was added. The heterogeneous mixture was stirred for $72 \mathrm{~h}$ at room temperature, until full conversion of the aldehyde (the disappearance of the aldehyde can be monitored by ${ }^{31} \mathrm{P}$ NMR). When the reaction was complete, the solvent was evaporated and the product was extracted with ethylacetate. The organic phase was washed with an aqueous solution of $\mathrm{NaOH}(1 \mathrm{M})$ three times. The organic phase was separated and dried over magnesium sulfate $\left(\mathrm{MgSO}_{4}\right)$. The solvent was evaporated to give the crude mixture as a solid foam. The solid can be purified by chromatography over a silica gel column (gradient of elution from hexane to hexane-diethyl ether $2: 1 \mathrm{v} / \mathrm{v}$, $\left.R_{\mathrm{f}} \sim 0.5\right)$ and obtained as a white foam (0.6 g, $\left.0.71 \mathrm{mmol}, 61 \%\right)$. If there is no other amine by-product, $\mathbf{L}^{\mathbf{5}}$ can also be purified by precipitation of the ammonium chloride salt ( $c f$. synthesis of $\mathbf{L}^{5} \cdot \mathbf{H C l}$ ) followed by deprotonation (a solution of $\mathbf{L}^{5} \cdot \mathbf{H C l}$ in dichloromethane is vigorously stirred with aqueous $\mathrm{NaOH}$ (1 M)). Single crystals for X-ray diffraction structure analysis were obtained by slow evaporation of a concentrated solution of $\mathbf{L}^{\mathbf{5}}$ in $\mathrm{CH}_{2} \mathrm{Cl}_{2} \cdot{ }^{1} \mathrm{H}$ NMR (300 MHz, $25{ }^{\circ} \mathrm{C}$, D6-acetone): $\delta=7.77(\mathrm{~m}$, 3H, H3), 7.30 (m, 21H, H-Ar), 7.12 (m, 15H, H-Ar) 6.72 (m, 3H, H6), $3.78\left(\mathrm{~d},{ }^{4} J_{\mathrm{P}-\mathrm{H}}=2.8 \mathrm{~Hz}, 6 \mathrm{H}, \mathrm{H} 1\right) ;{ }^{13} \mathrm{C}\left\{{ }^{1} \mathrm{H}\right\} \mathrm{NMR}(125 \mathrm{MHz}$, $\left.25^{\circ} \mathrm{C}, \mathrm{CDCl}_{3}\right): \delta=144.1\left(\mathrm{~d}, J_{\mathrm{P}-\mathrm{C}}=22.5 \mathrm{~Hz}, \mathrm{C} 2\right), 136.9\left(\mathrm{~d}, J_{\mathrm{P}-\mathrm{C}}=\right.$ $11.2 \mathrm{~Hz}, \mathrm{C} 8), 135.9$ (d, $\left.J_{\mathrm{P}-\mathrm{C}}=14.5 \mathrm{~Hz}, \mathrm{C} 7\right), 133.9$ (d, $J_{\mathrm{P}-\mathrm{C}}=19.5$ Hz, C9), 133.0 (C6), 128.8 (C3), 128.7 (d, $J_{\mathrm{P}-\mathrm{C}}=5.1 \mathrm{~Hz}, \mathrm{C} 4$ ), 128.5 (C11), 128.4 (d, $\left.J_{\mathrm{P}-\mathrm{C}}=6.9 \mathrm{~Hz}, \mathrm{C} 10\right), 126.7$ (C5), 55.7 (d, $\left.J_{\mathrm{P}-\mathrm{C}}=23.6 \mathrm{~Hz}, \mathrm{C} 1\right) ;{ }^{31} \mathrm{P}\left\{{ }^{1} \mathrm{H}\right\}\left(200 \mathrm{MHz}, 25^{\circ} \mathrm{C}\right.$, D6-acetone $): \delta=$ -16.3. Anal. calcd (\%) for $\mathrm{C}_{57} \mathrm{H}_{48} \mathrm{NP}_{3}$ : C, 81.51; H, 5.76; N, 1.67. Found: C, 81.44; H, 5.81; N, 1.55 .

\section{Synthesis of tris(2-(diphenylphosphino)benzyl)ammonium chloride (by protonation of $\mathrm{L}^{5}$ with $\left.\mathrm{HCl}\right)\left(\mathrm{L}^{5} \cdot \mathrm{HCl}\right)$}

$\mathbf{L}^{\mathbf{5}}$ was dissolved in diethyl ether and an etheral solution of $\mathrm{HCl}(1 \mathrm{M})$ was added dropwise until no further precipitate was formed. The solid was filtered off over celite and recovered by dissolution in dichloromethane $\left(\mathrm{CH}_{2} \mathrm{Cl}_{2}\right)$. The solvent was evaporated to dryness and $\mathbf{L}^{\mathbf{5}} \cdot \mathbf{H C l}$ was obtained as a white solid quantitatively. Single crystals for X-ray diffraction structure analysis were obtained by slow evaporation of a concentrated solution of $\mathbf{L}^{5} \cdot \mathbf{H C l}$ in $\mathrm{CHCl}_{3} \cdot{ }^{1} \mathrm{H} \mathrm{NMR}\left(300 \mathrm{MHz}, 25{ }^{\circ} \mathrm{C}\right.$, $\mathrm{CDCl}_{3}$ ): $\delta=8.72$ (brs, $1 \mathrm{H}, \mathrm{NH}$ ), 7.69 (d, $J=7.1 \mathrm{~Hz}, 4 \mathrm{H}, \mathrm{H}-\mathrm{Ar}$ ), 7.45-7.00 (brm, 38H, H-Ar), 5.12 (brs, 6H, N-CH ${ }_{2}$ ); ${ }^{31} \mathrm{P}\left\{{ }^{1} \mathrm{H}\right\}$ $\left(120 \mathrm{MHz}, 25{ }^{\circ} \mathrm{C}, \mathrm{CDCl}_{3}\right): \delta=-17.8$. Anal. calcd $(\%)$ for $\mathrm{C}_{57} \mathrm{H}_{49} \mathrm{ClNP}_{3}$ : C, 75.08; H, 5.42; N, 1.54. Found: C, 75.18; H, $5.54 ; \mathrm{N}, 1.55$.

Synthesis of $N, N$-bis( pyridin-2-yl)-1-(2-(diphenylphosphino)benzyl)methanamine $\left(\mathrm{N}_{3} \mathbf{P}, \mathrm{L}^{6}\right)$

2-(Diphenylphosphino)benzaldehyde (1.75 g, $6.12 \mathrm{mmol}$ ) and di-(2-picolylamine) $(1.08 \mathrm{~mL}, 6.12 \mathrm{mmol})$ were dissolved in 
1,2-dichloroethane $(20 \mathrm{~mL})$. After 5 min sodium triacetoxyborohydride (1.82 g, $12.24 \mathrm{mmol}$ ) was added. The reaction mixture was stirred at room temperature for $4 \mathrm{~h}$ before the reaction was diluted with ethylacetate and quenched by a saturated $\mathrm{NaHCO}_{3}$ solution. The aqueous phase was then extracted with AcOEt $(3 \times 15 \mathrm{~mL})$ and the organic layers were combined, dried over $\mathrm{MgSO}_{4}$ and solvents were removed under reduced pressure. The resulting yellow oil was then recrystallized from cold diethyl ether to yield a pale yellow solid $(2.45 \mathrm{~g}, 85 \%) .{ }^{1} \mathrm{H}$ NMR (300 MHz, $\mathrm{CDCl}_{3}$ ) $\delta 8.47$ (d, $\left.J=4.1 \mathrm{~Hz}, 2 \mathrm{H}, \mathrm{H1}\right), 7.79$ (dd, $J=7.1,4.4 \mathrm{~Hz}, 1 \mathrm{H}), 7.56(\mathrm{td}, J=7.7,1.8 \mathrm{~Hz}, 2 \mathrm{H}), 7.41-7.02(\mathrm{~m}$, $16 \mathrm{H}), 6.87(\mathrm{dd}, J=6.7,4.3 \mathrm{~Hz}, 1 \mathrm{H}), 3.94\left(\mathrm{~d},{ }^{4} J_{\mathrm{P}-\mathrm{H}}=2.0 \mathrm{~Hz}, 2 \mathrm{H}\right.$, H3), 3.75 (s, 4H, H2); ${ }^{13} \mathrm{C}$ NMR (75 $\left.\mathrm{MHz} \mathrm{CDCl}_{3}\right) \delta 159.7,149.0$, $137.1,136.9,136.4,134.1,133.9,129.2,128.9,128.7,128.6$, 127.2, 122.9, 121.9, 59.9, 57.0, 56.7; ${ }^{31} \mathrm{P}$ NMR (121 MHz, $\left.\mathrm{CDCl}_{3}\right) \delta-16.4$.

\section{General procedure: synthesis of 1-3 and 7-9}

Into a solution of an appropriate pro-ligand $(0.2 \mathrm{mmol})$ in THF (10 mL), sodium hydride $(9.6 \mathrm{mg}, 0.4 \mathrm{mmol})$ was added. The mixture was stirred at room temperature for $10 \mathrm{~min}$ and a dichloride salt ( $\mathrm{Zn}$ or $\mathrm{Co}, 0.2 \mathrm{mmol}$ ) was then added. The mixture was stirred at $60{ }^{\circ} \mathrm{C}$ for $48 \mathrm{~h}$ and then filtered through a metal cannula equipped with a paper filter. THF was removed and the solid obtained was washed three times with pentane. The final product was dried under vacuum for at least $24 \mathrm{~h}$.

\section{$\left(\mathbf{L}^{1}\right) \mathrm{ZnCl}(1)$}

A white solid was obtained in $90 \%$ yield. ${ }^{1} \mathrm{H}$ NMR $(400 \mathrm{MHz}$, $\left.25{ }^{\circ} \mathrm{C}, \mathrm{CDCl}_{3}\right): \delta=9.43(\mathrm{~d}, J=2.8 \mathrm{~Hz}, 2 \mathrm{H}, \mathrm{H}-\mathrm{Ar}-\mathrm{pyr}), 7.81(\mathrm{~m}$, 2H, H-Ar-pyr), 7.24 (m, 2H, H-Ar-pyr), 7.11 (d, $J=2.3 \mathrm{~Hz}, 1 \mathrm{H}$, H-Ar-phenol), 6.79 (d, $J=2.3 \mathrm{~Hz}, \mathrm{H}$-Ar-phenol), 4.10 (d, $J=15.7$ Hz, 2H, H-Bz-pyr), 3.86 (d, $J=15.7$ Hz, 2H, H-Bz-pyr), 3.78 (s, $2 \mathrm{H}, \mathrm{H}-\mathrm{Bz}-\mathrm{phenol}$ ), 1.42 (s, 9H, H- $t \mathrm{Bu}), 1.23$ (s, 9H, H- $t \mathrm{Bu}) ;{ }^{13} \mathrm{C}$ NMR (100 MHz, $\left.25{ }^{\circ} \mathrm{C}, \mathrm{CDCl}_{3}\right): \delta=164.1$ (C-O), 155.2, 150.8, $139.8,139.2,135.2,125.5,124.3,124.1,123.1,121.5,60.3$ (C-Bz-phenol), 58.1 (C-Bz-pyr), 36.3 (C-qua-tBu), 33.9 (C-qua$t \mathrm{Bu}), \quad 32.0$ (C-Me), 29.9 (C-Me); Anal. calcd (\%) for $\mathrm{C}_{27} \mathrm{H}_{34} \mathrm{~N}_{3} \mathrm{OClZn}: \mathrm{C}, 62.67 ; \mathrm{H}, 6.62 ; \mathrm{N}, 8.12$. Found: C, 62.55; H, 6.67; N, 8.08.

\section{$\left(\mathbf{L}^{2}\right) \mathrm{ZnCl}(2)$}

White solid; $56 \%$ yield. ${ }^{1} \mathrm{H}$ NMR $\left(300 \mathrm{MHz}, 25{ }^{\circ} \mathrm{C}, \mathrm{CDCl}_{3}\right): \delta=$ 9.17 (d, $J=4.9 \mathrm{~Hz}, 2 \mathrm{H}, \mathrm{H}-\mathrm{Ar}-\mathrm{pyr}), 7.82$ (t, $J=4.9 \mathrm{~Hz}, 2 \mathrm{H}, \mathrm{H}-\mathrm{Ar}-$ pyr), 7.41 (m, 2H, H-Ar), 7.13-7.39 (m, 8H, H-Ar), 7.03 (d, $J=$ $2.2 \mathrm{~Hz}, \mathrm{H}-A r-p h e n o l), 6.83-6.97$ (m, 9H, H-Ar), 6.68 (d, $J=$ $2.2 \mathrm{~Hz}, \mathrm{H}$-Ar-phenol), 3.89 (d, $J=14.7 \mathrm{~Hz}, 2 \mathrm{H}, \mathrm{H}-\mathrm{Bz}$ ), 3.55 (m, 4H, H-Bz), 2.13 (s, 3H, H-Me); Anal. calcd (\%) for $\mathrm{C}_{39} \mathrm{H}_{34} \mathrm{~N}_{3} \mathrm{OClZn}$ : C, 70.81; H, 5.18; N, 6.35. Found: C, 70.77; H, 5.12; N, 6.37. Single crystals for X-ray diffraction structure analysis were obtained by slow evaporation of a concentrated solution of 2 in $\mathrm{CDCl}_{3}$.

\section{$\left(\mathbf{L}^{3}\right) \mathrm{ZnCl}(3)$}

White solid; $85 \%$ yield. ${ }^{1} \mathrm{H}$ NMR $\left(300 \mathrm{MHz}, 25{ }^{\circ} \mathrm{C}, \mathrm{CDCl}_{3}\right): \delta=$ 9.5 (d $J=4.8 \mathrm{~Hz}, 1 \mathrm{H}, \mathrm{H}-\mathrm{Ar}-\mathrm{pyr}), 7.65-7.75$ (m, 3H, H-Ar), 7.51-7.57 (m, 2H, H-Ar), 7.22-7.47 (m, 9H, H-Ar), 7.10-7.17 (m, $3 \mathrm{H}, \mathrm{H}-\mathrm{Ar}$ ), 6.94 (t, $J=7.6 \mathrm{~Hz}, 1 \mathrm{H}, \mathrm{H}-\mathrm{Ar}), 6.70$ (d, $J=2.8 \mathrm{~Hz}, 1 \mathrm{H}$, H-Ar-phenol), 4.23 (d, $J=15.2 \mathrm{~Hz}, 1 \mathrm{H}, \mathrm{H}-\mathrm{Bz}$ ), 4.04 (d, $J=16.4$ Hz, 2 h, H-Bz), 3.520 (m, 2H, H-Bz), 3.14 (d, $J=16.4 \mathrm{~Hz}, 1 \mathrm{H}$, $\mathrm{H}-\mathrm{Bz}), 1.51$ (s, 9H, H-tBu), 1.22 (s, 9H, H-tBu); ${ }^{31} \mathrm{P}\left\{{ }^{1} \mathrm{H}\right\}$ $\left(120 \mathrm{MHz}, 25{ }^{\circ} \mathrm{C}, \mathrm{CDCl}_{3}\right): \delta=-20.6$. Anal. calcd (\%) for $\mathrm{C}_{40} \mathrm{H}_{44} \mathrm{~N}_{2} \mathrm{OPClZn}$ : C, 68.57; H, 6.33; N, 4.00. Found: C, 68.48; $\mathrm{H}, 6.37$; N, 3.93.

\section{$\left(\mathbf{L}^{\mathbf{1}}\right) \operatorname{CoCl}(7)$}

Green solid; 88\% yield. ${ }^{1} \mathrm{H}$ NMR (300 MHz, $\left.\mathrm{CDCl}_{3}\right) \delta 121.1$ (700, 2H), 55.8 (190, 2H), $46.3(75,1 \mathrm{H}), 36.8$ (160, 2H), 29.3 $(125,1 \mathrm{H})$ 4.6-3.5 (2 peaks, $18 \mathrm{H})$; $-0.7(2 \mathrm{H})$; magnetic susceptibility $\left(\mathrm{CDCl}_{3}, 293 \mathrm{~K}\right) \mu_{\text {eff }}=4.8 \mu_{\mathrm{B}}$; ESI MS $m / z 516.7([\mathrm{M}-\mathrm{Cl}+$ $\left.\mathrm{MeCN}]^{+}\right), 511.5\left([\mathrm{M}+\mathrm{H}]^{+}\right), 475.6\left([\mathrm{M}-\mathrm{Cl}]^{+}\right), 258.9([\mathrm{M}+\mathrm{H}-$ $\left.\mathrm{Cl}+\mathrm{MeCN}]^{2+}\right), 238.3\left([\mathrm{M}+\mathrm{H}-\mathrm{Cl}]^{2+}\right) ; \mathrm{UV}$-visible $\left(\mathrm{CH}_{2} \mathrm{Cl}_{2}\right) \lambda(\varepsilon)$ $603 \mathrm{~nm}\left(153 \mathrm{M}^{-1} \mathrm{~cm}^{-1}\right), 552 \mathrm{~nm}\left(122 \mathrm{M}^{-1} \mathrm{~cm}^{-1}\right), 491 \mathrm{~nm}$ (126 $\mathrm{M}^{-1} \mathrm{~cm}^{-1}$ ). Anal. calcd (\%) for $\mathrm{C}_{27} \mathrm{H}_{34} \mathrm{~N}_{3}$ OClCo: C, 63.47; H, 6.71; N, 8.22. Found: C, 63.58; H, 6.80; N, 8.16.

\section{$\left(\mathbf{L}^{3}\right) \operatorname{CoCl}(8)$}

Green solid; $55 \%$ yield. Anal. calcd (\%) for $\mathrm{C}_{39} \mathrm{H}_{34} \mathrm{~N}_{3}$ OClCo: C, 71.50; H, 5.23; N, 6.41. Found: C, 70.46; H, 5.17; N, 6.38.

\section{$\left(\mathbf{L}^{2}\right) \operatorname{CoCl}(9)$}

Green solid; $80 \%$ yield. Anal. calcd (\%) for $\mathrm{C}_{40} \mathrm{H}_{44} \mathrm{~N}_{2}$ OPClCo: C, 69.21; H, 6.39; N, 4.04. Found: C, 69.11; H, 6.48; N, 3.91. UV/visible $\left(\mathrm{CH}_{2} \mathrm{Cl}_{2}\right) \lambda(\varepsilon) 633 \mathrm{~nm}\left(308 \mathrm{M}^{-1} \mathrm{~cm}^{-1}\right), 575 \mathrm{~nm}$ $\left(228 \mathrm{M}^{-1} \mathrm{~cm}^{-1}\right)$.

\section{Synthesis of $\left(\mathrm{L}^{4}\right) \mathrm{ZnCl}_{2}(4)$}

A solution of zinc dichloride $(0.04 \mathrm{~g}, 0.29 \mathrm{mmol})$ and $\mathbf{L}^{4}$ $(0.204 \mathrm{~g}, 0.31 \mathrm{mmol})$ in tetrahydrofuran $(3 \mathrm{~mL})$ was stirred overnight at $50{ }^{\circ} \mathrm{C}$. Then, the solvent was evaporated and the white solid obtained was washed three times with pentane. Complex 4 was dried thoroughly under vacuum and obtained as a white solid, containing 0.1 mole of THF (confirmed by ${ }^{1} \mathrm{H}$ NMR analysis) (0.150 g, $0.23 \mathrm{mmol}, 78 \%) .{ }^{1} \mathrm{H}$ NMR $(300 \mathrm{MHz}$, $25{ }^{\circ} \mathrm{C}, \mathrm{CDCl}_{3}$ ): $\delta=9.33$ (brs, $1 \mathrm{H}, \mathrm{H}-\mathrm{Ar}$ ), 7.90-6.60 (br, $31 \mathrm{H}, \mathrm{H}-\mathrm{Ar}$ ), 4.60-3.70 (br, 6H, $\left.\mathrm{CH}_{2}\right) ;{ }^{31} \mathrm{P}\left\{{ }^{1} \mathrm{H}\right\}\left(120 \mathrm{MHz}, 25{ }^{\circ} \mathrm{C}\right.$, $\left.\mathrm{CDCl}_{3}\right): \delta=-16.3$. Anal. calcd $(\%)$ for $\left[\mathrm{C}_{44} \mathrm{H}_{38} \mathrm{Cl}_{2} \mathrm{~N}_{2} \mathrm{P}_{2} \mathrm{Zn}\right]$. $[\mathrm{THF}]_{0.1}$ : C, 66.62; H, 4.89; N, 3.50. Found: C, 66.50; H, 4.75; N, 3.47 .

\section{Synthesis of $\left(\mathrm{L}^{5}\right) \mathrm{ZnCl}_{2}(5)$}

A solution of zinc dichloride $(0.03 \mathrm{~g}, 0.22 \mathrm{mmol})$ and $\mathbf{L}^{\mathbf{5}}$ $(0.20 \mathrm{~g}, 0.24 \mathrm{mmol})$ in tetrahydrofuran $(3 \mathrm{~mL})$ was stirred overnight at $50{ }^{\circ} \mathrm{C}$. Then, the solvent was evaporated and the white solid obtained was washed three times with pentane. The white solid 5 was dried thoroughly under vacuum $(0.160 \mathrm{~g}$, $0.16 \mathrm{mmol}, 72 \%) .{ }^{1} \mathrm{H}$ NMR (400 $\left.\mathrm{MHz}, 25{ }^{\circ} \mathrm{C}, \mathrm{CDCl}_{3}\right): \delta=$ 7.75-6.70 (m, 42H, H-Ar), 4.89 (br, $\mathrm{CH}_{2}$ ), 4.09 (br, $\mathrm{CH}_{2}$ ), 3.71 
$(\mathrm{s}, \mathrm{CH}) ;{ }^{31} \mathrm{P}\left\{{ }^{1} \mathrm{H}\right\}\left(120 \mathrm{MHz}, 25{ }^{\circ} \mathrm{C}, \mathrm{CDCl}_{3}\right): \delta=-11.1,-16.3$, -18.8. Anal. calcd (\%) for $\mathrm{C}_{57} \mathrm{H}_{48} \mathrm{Cl}_{2} \mathrm{NP}_{3} \mathrm{Zn}$ : C, 70.13; H, 4.96; $\mathrm{N}, 1.43$. Found: C, 70.05; H, 5.11; N, 1.35.

\section{Synthesis of $\left(\mathrm{L}^{6}\right) \mathrm{ZnCl}_{2}(6)$}

A solution of zinc dichloride $(0.03 \mathrm{~g}, 0.22 \mathrm{mmol})$ and $\mathbf{L}^{6}$ $(0.11 \mathrm{~g}, 0.24 \mathrm{mmol})$ in tetrahydrofuran $(3 \mathrm{~mL})$ was stirred overnight at $50{ }^{\circ} \mathrm{C}$. Then, the solvent was evaporated and the white solid obtained was washed three times with pentane. The white solid 6 was then dried thoroughly under vacuum (0.140 g, $0.23 \mathrm{mmol}, 96 \%) .{ }^{1} \mathrm{H}$ NMR (300 MHz, $25{ }^{\circ} \mathrm{C}, \mathrm{CDCl}_{3}$ ) $\delta 9.19(\mathrm{~d}, J=4.8 \mathrm{~Hz}, 2 \mathrm{H}), 8.12(\mathrm{~s}, 1 \mathrm{H}), 7.94(\mathrm{~s}, 4 \mathrm{H}), 7.62-7.02$ $(\mathrm{m}, 14 \mathrm{H}), 6.77(\mathrm{t}, J=8.5 \mathrm{~Hz}, 1 \mathrm{H}), 4.57(\mathrm{br}, 4 \mathrm{H}), 4.32(\mathrm{~s}, 2 \mathrm{H}) .{ }^{13} \mathrm{C}$ NMR (75 MHz, $\left.\mathrm{CDCl}_{3}\right) \delta 156.17,148.72,141.17,139.64,139.43$, $135.45,135.33,134.38,133.61,133.43,132.46,131.22,129.21$, $129.08,127.25,126.88,126.75,126.29,125.93,124.22,58.23$, 57.09, 31.36, 22.43, 13.93; ${ }^{31} \mathrm{P}$ NMR (121 MHz, $25{ }^{\circ} \mathrm{C}, \mathrm{CDCl}_{3}$ ) $\delta-18.04$.

\section{Synthesis of $\left(\mathrm{L}^{4}\right) \mathrm{CoCl}_{2}(10)$}

A solution of cobalt dichloride $(0.03 \mathrm{~g}, 0.23 \mathrm{mmol})$ and $\mathbf{L}^{4}$ $(0.167 \mathrm{~g}, 0.25 \mathrm{mmol})$ in tetrahydrofuran $(3 \mathrm{~mL})$ was stirred overnight at $50{ }^{\circ} \mathrm{C}$ (a purple precipitate formed instantaneously). Then, the solvent was removed with a cannula and the purple solid was washed with tetrahydrofuran and dried thoroughly under vacuum to give $\mathbf{1 0}$ as a pure compound (0.144 g, $0.18 \mathrm{mmol}, 80 \%)$. Anal. calcd (\%) for $\mathrm{C}_{44} \mathrm{H}_{38} \mathrm{Cl}_{2} \mathrm{ColN}_{2} \mathrm{P}_{2}$ : C, 67.19; H, 4.87; N, 3.56. Found: C, 67.08; $\mathrm{H}, 4.93$; N, 3.45 .

\section{Synthesis of $\left(\mathrm{L}^{5}\right) \mathrm{CoCl}_{2}(11)$}

A solution of cobalt dichloride $(0.03 \mathrm{~g}, 0.23 \mathrm{mmol})$ and $\mathbf{L}^{5}$ $(0.214 \mathrm{~g}, 0.25 \mathrm{mmol})$ in tetrahydrofuran $(3 \mathrm{~mL})$ was stirred overnight at $50{ }^{\circ} \mathrm{C}$. A blue solution was obtained with the formation of a brown precipitate. Then, the solvent was evaporated and the brown solid obtained was washed three times with pentane. The brown solid $\mathbf{1 1}$ was dried thoroughly under vacuum (0.205 g, $0.21 \mathrm{mmol}, 92 \%)$. Anal. calcd (\%) for $\mathrm{C}_{57} \mathrm{H}_{48} \mathrm{Cl}_{2} \mathrm{CoNP}_{3}$ : C, 70.60; H, 4.99; N, 1.44. Found: C, 70.48; $\mathrm{H}, 4.89 ; \mathrm{N}, 1.55$; UV/visible $\left(\mathrm{CH}_{2} \mathrm{Cl}_{2}\right) \lambda(\varepsilon) 733 \mathrm{~nm}\left(91 \mathrm{M}^{-1} \mathrm{~cm}^{-1}\right)$, $665 \mathrm{~nm}\left(163 \mathrm{M}^{-1} \mathrm{~cm}^{-1}\right), 600 \mathrm{~nm}\left(144 \mathrm{M}^{-1} \mathrm{~cm}^{-1}\right), 497 \mathrm{~nm}$ $\left(96 \mathrm{M}^{-1} \mathrm{~cm}^{-1}\right)$.

\section{Synthesis of $\left(\mathrm{L}^{6}\right) \mathrm{CoCl}_{2}(12)$}

A solution of cobalt dichloride $(0.03 \mathrm{~g}, 0.23 \mathrm{mmol})$ and $\mathbf{L}^{\mathbf{6}}$ $(0.12 \mathrm{~g}, 0.25 \mathrm{mmol})$ in tetrahydrofuran $(3 \mathrm{~mL})$ was stirred overnight at $50{ }^{\circ} \mathrm{C}$. A blue solution was obtained with the formation of a brown precipitate. Then, the solvent was evaporated and the brown solid obtained was washed three times with pentane. The brown solid 12 was dried thoroughly under vacuum (0.13 g, $0.22 \mathrm{mmol}, 95 \%) .{ }^{1} \mathrm{H}$ NMR $(300 \mathrm{MHz}$, $\left.25{ }^{\circ} \mathrm{C}, \mathrm{CDCl}_{3}\right) \delta 131.4(800,2 \mathrm{H}), 64.3(75,2 \mathrm{H}), 43.0(60,2 \mathrm{H})$, $13.6(30,4 \mathrm{H}), 13.2(40,2 \mathrm{H}) 3.6(25,1 \mathrm{H}),-3.3(45,1 \mathrm{H}),-5.6$ $(65,2 \mathrm{H}),-7.5(110,2 \mathrm{H}),-12.5(240,4 \mathrm{H})$; magnetic susceptibility $\left(\mathrm{CDCl}_{3}, 293 \mathrm{~K}\right) \mu_{\mathrm{eff}}=4.1 \mu_{\mathrm{B}}(\mathrm{SQUID}, 293 \mathrm{~K}) \mu_{\mathrm{eff}}=3.9 \mu_{\mathrm{B}}$; ESI MS $m / z 567.3\left([\mathrm{M}-\mathrm{Cl}]^{+}\right), 287.0\left([\mathrm{M}-2 \mathrm{Cl}+\mathrm{MeCN}]^{2+}\right)$,
$266.3\left([\mathrm{M}-2 \mathrm{Cl}]^{2+}\right)$; UV-visible $\left(\mathrm{CH}_{2} \mathrm{Cl}_{2}\right) \lambda(\varepsilon) 660 \mathrm{~nm}\left(130 \mathrm{M}^{-1}\right.$ $\left.\mathrm{cm}^{-1}\right), 520 \mathrm{~nm}\left(175 \mathrm{M}^{-1} \mathrm{~cm}^{-1}\right)$.

\section{Typical polymerization procedure}

All polymerizations were performed under argon in a $15 \mathrm{~mL}$ flame dried Schlenk tube equipped with a Teflon coated stirring bar. In a glove box, a Schlenk tube was charged with the appropriate complex (0.009 $\mathrm{mmol})$, benzyl alcohol (0.01 g, $0.090 \mathrm{mmol})$ and $\mathrm{rac}$-lactide $(1.30 \mathrm{~g} .9 \mathrm{mmol})$ and then outside of the glove box, the tube was immersed in a $130{ }^{\circ} \mathrm{C}$ oil bath. The reaction mixture was vigorously stirred for the desired time and the polymerization was quenched by rapid cooling of the reaction vessel. Conversion was determined by ${ }^{1} \mathrm{H}$ NMR analysis of the crude mixture (integrating the methyl region in the spectrum). The crude mixture was then dissolved in $8 \mathrm{~mL}$ of dichloromethane and the polymer further precipitated from $400 \mathrm{~mL}$ of ice-cold ethanol. The resulting polymer was dried under vacuum at $50{ }^{\circ} \mathrm{C}$ until the weight was constant. In the case of a polymerization with lower conversion, the crude was precipitated from an appropriate mixture of diethyl ether and pentane.

\section{Acknowledgements}

CNRS, ENSCP, ANR (grant ANR-10-PDOC-010-01), Fondation Pierre-Gilles de Gennes, and the French Ministry of Research and Higher Education are thanked for financial support of this work. The authors would like to thank Purac for a generous loan of rac-lactide. C. M. T. is grateful to the Institut Universitaire de France.

\section{References}

1 (a) R. E. Drumright, P. R. Gruber and D. E. Henton, $A d v$. Mater., 2000, 12, 1841-1846; (b) S. Mecking, Angew. Chem., Int. Ed., 2004, 43, 1078-1085.

2 (a) H. R. Kricheldorf and I. Kreiser-Saunders, Macromol. Symp., 1996, 103, 85-102; (b) M. Vert, Macromol. Symp., 2000, 153, 333-342.

3 (a) D. W. Grijpma, A. J. Nijenhuis, P. G. T. van Wijk and A. J. Pennings, Polym. Bull., 1992, 29, 571-578; (b) J. W. Leenslag, A. J. Pennings, R. R. M. Bos, F. R. Rozema and G. Boering, Biomaterials, 1987, 8, 70-73; (c) E. Chiellini and R. Solaro, Adv. Mater., 1996, 8, 305-313. 4 S. K. Ritter, Chem. Eng. News, 2002, 80, 26-30.

5 (a) O. Dechy-Cabaret, B. Martin-Vaca and D. Bourissou, Chem. Rev., 2004, 104, 6147-6176; (b) C. M. Thomas, Chem. Soc. Rev., 2010, 39, 165-173; (c) M. J.-L. Tschan, E. Brulé, P. Haquette and C. M. Thomas, Polym. Chem., 2012, 3, 836851.

6 Inspired by the cooperativity of dizinc sites in hydrolytic enzymes, Hillmyer and Tolman have demonstrated that dinuclear zinc complexes supported by a bulky monophenoxide ligand polymerize LA with good control and at a rate 
faster than any other Zn-containing system reported previously. (a) C. K. Williams, N. R. Brooks, M. A. Hillmyer and W. B. Tolman, Chem. Commun., 2002, 2132-2133; (b) C. K. Williams, L. E. Breyfogle, S. K. Choi, W. Nam, V. G. Young Jr., M. A. Hillmyer and W. B. Tolman, J. Am. Chem. Soc., 2003, 125, 11350-11359.

7 (a) G. Parkin, Chem. Rev., 2004, 104, 699-767; (b) A. Badarau and M. I. Page, Biochemistry, 2006, 45, 10654-10666.

8 In particular, metallo- $\beta$-lactamases are important native zinc enzymes that catalyze the hydrolysis of $\beta$-lactam antibiotics.

9 The motivation for their use comes from the fact that important zinc enzymes such as the peptidase astacin exhibit amidase activity involving the cleavage of amide bonds. Astacin is an endopeptidase for which the active site has a unusual trigonal bipyramidal geometry, with the zinc coordinated to three histidine residues, a tyrosine residue, and a water molecule. See for instance: (a) W. Bode, F. Goumis-Rüth, R. Huber, R. Zwilling and W. Stöcker, Nature, 1992, 358, 164167; (b) F. X. Goumis-Rüth, W. Stöcker, R. Huber, R. Zwilling and W. Bode, J. Mol. Biol., 1993, 229, 945968.

10 See for instance: (a) R. Alsfasser, S. Trofimenko, A. Looney, G. Parkin and H. Vahrenkamp, Inorg. Chem., 1991, 30, 4098-4100; (b) A. Looney, G. Parkin, R. Alsfasser, M. Ruf and H. Vahrenkamp, Angew. Chem., Int. Ed. Engl., 1992, 31, 92-93; (c) A. Looney, R. Han, K. McNeill and G. Parkin, J. Am. Chem. Soc., 1993, 115, 4690-4697; (d) R. Alsfasser, M. Ruf, S. Trofimenko and H. Vahrenkamp, Chem. Ber., 1993, 126, 703-710; (e) W. Sattler and G. Parkin, Polyhedron, 2012, 32, 41-48.

11 (a) A. Abufarag and H. Vahrenkamp, Inorg. Chem., 1995, 34, 3279-3284; (b) A. Trösch and H. Vahrenkamp, Eur. J. Inorg. Chem., 1998, 827-832; (c) A. Trösch and H. Vahrenkamp, Inorg. Chem., 2001, 2305-2311; (d) Z. Zheng, G. Zhao, R. Fablet, M. Bouyahyi, C. M. Thomas, T. Roisnel, O. Casagrande Jr. and J.-F. Carpentier, New J. Chem., 2008, 32, 2279-2291.

12 T. Aida, Y. Maekawa, S. Asano and S. Inoue, Macromolecules, 1988, 21, 1195-1202.

13 See for instance: (a) A. Amgoune, C. M. Thomas, T. Roisnel and J.-F. Carpentier, Chem.-Eur. J., 2006, 12, 169-179; (b) J. Fang, M. J.-L. Tschan, T. Roisnel, X. Trivelli, R. M. Gauvin, C. M. Thomas and L. Maron, Polym. Chem., 2013, 4, 360-367.

14 A. F. Abdel-Magib, K. G. Carson, B. D. Harris, C. A. Maryanoff and R. D. Shah, J. Org. Chem., 1996, 61, 3849-3862.

15 P. N. Liu, F. H. Su, T. B. Wen, H. H.-Y. Sung, I. D. Williams and G. Jia, Chem.-Eur., J., 2010, 16, 7889-7897.

16 (a) A. Beitat, S. P. Foxon, C.-C. Brombach, H. Hausman, F. W. Heinnemann, F. Hampel, U. Monkowius, C. Hirtelehmer, G. Knoör and S. Schindler, Dalton Trans., 2011, 40, 5090-5101.
17 S. Groysman, E. Sergeeva, I. Goldberg and M. Kol, Eur. J. Inorg. Chem., 2006, 2739-2745.

18 The $\tau$ value ranges from 0 (square pyramidal) to 1 (trigonal bipyramidal): (a) A. W. Addison, T. N. Rao, J. Reedijk, J. van Rijn and G. C. Verschoor, J. Chem. Soc., Dalton Trans., 1984, 1349-1356; (b) J. Ternel, L. Delevoye, F. Agbossou-Niedercorn, T. Roisnel, R. M. Gauvin and C. M. Thomas, Dalton Trans., 2010, 39, 3802-3804.

19 (a) G. N. La Mar, W. Horrocks Jr. and R. H. Holm, NMR of Paramagnetic Molecules: Principles and Applications, Academic Press, New York, 1973; (b) I. Bertini, C. Luchinat and G. Parigi, Solution NMR of Paramagnetic Molecules, Elsevier, Amsterdam, 2001; (c) F. H. Köhler, Magnetism: Molecules to Materials, Wiley-VCH Verlag $\mathrm{GmbH}$, Weinheim, Germany, 2001, p. 379.

20 J. Mao, Y. Zhang and E. Oldfield, J. Am. Chem. Soc., 2002, 124, 13911-13920.

21 M. Kruck, D. C. Sauer, M. Enders, H. Wadepohl and L. H. Gade, Dalton Trans., 2011, 40, 10406-10415.

22 P. Fernández, H. Pritzkow, J. J. Carbó, P. Hofmann and M. Enders, Organometallics, 2007, 26, 4402-4412.

23 This hyperfine shift depends on temperature and hyperfine tensors. The complete equations can be simplified by considering two contributions to the hyperfine shift: the Fermi contact shift and the pseudocontact shift. The Fermi contact shift is the consequence of the spin delocalization on the molecule through the molecular orbitals hosting unpaired electrons. It is proportional to the residual spin density at the nucleus. The pseudocontact shift is caused by a dipolar interaction between the electronic spin magnetic moment created by the unpaired electrons and the spin magnetic moment of the nucleus. As it is a spatial interaction, the shift depends strongly on the distance between the nucleus and the paramagnetic moment and the consequence is the farther the nucleus is, the smaller is the pseudocontact shift contribution. Moreover, in covalently bound species, it is considered negligible compared to the Fermi contact shift. The presence of an electronic spin in a molecule also has an influence on the $T_{1}$ and $T_{2}$ relaxation times and the peak width on the spectrum. The nuclear spin relaxes faster and the peaks are broadened. The phenomena in question are, again, the Fermi contact and the pseudocontact interactions. The predominant term depends on the molecule albeit the pseudocontact term is often the greater.

24 One should not forget that it can be over- or underestimated.

25 A. Beitat, S. P. Foxon, C.-C. Brombach, H. Hausmann, F. W. Heinemann, F. Hampel, U. Monkowius, C. Hirtenlehner, G. Knör and S. Schindler, Dalton Trans., 2011, 40, 5090-5101.

26 (a) D. Mandon, A. Machkour, S. Goetz and R. Welter, Inorg. Chem., 2002, 41, 5364-5372; (b) J. England, R. Gondhia, L. Bigorra-Lopez, A. R. Petersen, A. J. P. White and G. J. P. Britovsek, Dalton Trans., 2009, 5319-5334. 
27 (a) R. D. Shannon and C. T. Prewitt, Acta Crystallogr., Sect. B: Struct. Crystallogr. Cryst. Chem., 1969, 25, 925-946; (b) R. D. Shannon, Acta Crystallogr., Sect. A: Cryst. Phys., Diffr., Theor. Gen. Cryst., 1976, 32, 751-767.

28 D. F. Evans, J. Chem. Soc., 1959, 2003-2005.

29 K. De Buysser, G. G. Herman, E. Bruneel, S. Hoste and I. Van Driessehe, Chem. Phys., 2005, 315, 286-292.

30 R. W. Handel, H. Willms, G. B. Jameson, K. J. Berry, B. Moubaraki, K. S. Murray and S. Brooker, Eur. J. Inorg. Chem., 2010, 3317-3327.

31 (a) J. Wu, T.-L. Yu, C.-T. Chen and C.-C. Lin, Coord. Chem. Rev., 2006, 250, 602-626; (b) K. Nakano, N. Kosaka, T. Hiyama and K. Nozaki, Dalton Trans., 2003, 4039-4050; (c) R. H. Platel, L. M. Hodgson and C. K. Williams, Polym. Rev., 2008, 48, 11-63; (d) I. dos Santos Vieira and S. Herres-Pawlis, Eur. J. Inorg. Chem., 2012, 765-774; (e) J. Guo, P. Haquette, J. Martin, K. Salim and C. M. Thomas, Angew. Chem., Int. Ed., 2013, 52, 13584-13587.
32 (a) I. T. Horvath and P. T. Anastas, Chem. Rev., 2007, 107, 2169-2173; (b) P. Gupta and V. Kumar, Eur. Polym. J., 2007, 43, 4053-4074.

33 Z. Zhong, P. J. Dijkstra and J. Feijen, Angew. Chem., Int. Ed., 2002, 41, 4510-4513.

34 L. E. Breyfogle, C. K. Williams, V. G. Young, M. A. Hillmyer and W. B. Tolman, Dalton Trans., 2006, 928-936.

35 Y. Chunxiang, X. Xiaoping, Z. Yong and J. Shunjun, Chin. J. Chem., 2012, 30, 1474-1478.

36 Complexes $\mathbf{6}$ and $\mathbf{1 2}$ are insoluble in melt lactide and could not be tested.

37 J. Börner, U. Flörke, K. Huber, A. Döring, D. Kuckling and S. Herres-Pawlis, Chem.-Eur. J., 2009, 15, 23622376.

38 A. Amgoune, C. M. Thomas and J.-F. Carpentier, Macromol. Rapid Commun., 2007, 28, 693-697.

39 J. E. Hoots, T. B. Rauchfuss and D. B. Wrobleski, Inorg. Synthesis, 1982, 21, 175-178. 